\title{
Environmental impacts and constraints associated with the production of major food crops in Sub-Saharan Africa and South Asia
}

\author{
Travis W. Reynolds ${ }^{1}$ - Stephen R. Waddington ${ }^{2}$ - C. Leigh Anderson ${ }^{3}$. \\ Alexander $\mathrm{Chew}^{3} \cdot$ Zoe True $^{3} \cdot$ Alison Cullen $^{3}$
}

Received: 5 February 2015 / Accepted: 7 June 2015 /Published online: 7 July 2015

(C) The Author(s) 2015. This article is published with open access at Springerlink.com

\begin{abstract}
Many environmental factors constrain the production of major food crops in Sub-Saharan Africa and South Asia. At the same time, these food production systems themselves have a range of negative impacts on the environment. In this paper we review the published literature and assess the depth of recent research (since 2000) on crop x environment interactions for rice, maize, sorghum/millets, sweetpotato/yam and cassava in these two regions. We summarize current understandings of the environmental impacts of crop production systems prior to crop production, during production and postproduction, and emphasize how those initial environmental impacts become new and more severe environmental constraints to crop yields. Pre-production environmental interactions relate to agricultural expansion or intensification, and include soil degradation and erosion, the loss of wild
\end{abstract}

Travis W. Reynolds

twreynol@colby.edu

Stephen R. Waddington

srwaddington@gmail.com

C. Leigh Anderson

cla@u.washington.edu

Alexander Chew

alexander.epar@gmail.com

Zoe True

zoe.epar@gmail.com

Alison Cullen

alison@u.washington.edu

1 Environmental Studies Program, Colby College, Waterville, ME 04901, USA

2 Apartado Postal 4-205, Colonia Chapultepec, Cuernavaca, Morelos CP62451, Mexico

3 Daniel J. Evans School of Public Affairs, University of Washington, Seattle, WA 98195, USA biodiversity, loss of food crop genetic diversity and climate change. Those during crop production include soil nutrient depletion, water depletion, soil and water contamination, and pest resistance/outbreaks and the emergence of new pests and diseases. Post-harvest environmental interactions relate to the effects of crop residue disposal, as well as crop storage and processing. We find the depth of recent publications on environmental impacts is very uneven across crops and regions. Most information is available for rice in South Asia and maize in Sub-Saharan Africa where these crops are widely grown and have large environmental impacts, often relating to soil nutrient and water management. Relatively few new studies have been reported for sorghum/millets, sweetpotato/yam or cassava, despite their importance for food security on large areas of marginal farmland in Sub-Saharan Africa - however, there is mounting evidence that even these low-input crops, once thought to be environmentally benign, are contributing to cycles of environmental degradation that threaten current and future food production. A concluding overview of the emerging range of published good practices for smallholder farmers highlights many opportunities to better manage crop $\mathrm{x}$ environment interactions and reduce environmental impacts from these crops in developing countries.

Keywords Sustainable agriculture $\cdot$ Publication analysis · Good management practices $\cdot$ Rice $\cdot$ Maize .

Sorghum / millets · Sweetpotato / yam · Cassava

\section{Introduction}

A wide range of naturally occurring biotic and abiotic constraints, including poor soils, water scarcity, crop pests/diseases/weeds, and unsuitable temperatures, are well-known to reduce the productivity of food crops, leading to low 
efficiencies of input use, suppressed crop output, and ultimately reduced food security (e.g., Strange and Scott 2005; Gregory et al. 2005; Lal 2009; Waddington et al. 2010; Knox et al. 2012). But there has also been growing concern that farming practices themselves, both in extensive food crop production systems (found widely in Sub-Saharan Africa) and intensifying systems (common in South Asia) are exacerbating biotic and abiotic constraints on food production through negative impacts on the environment (Poppy et al. 2014; Dogliotti et al. 2014; Chartres and Noble 2015). Common examples include environmental degradation through agriculture-related deforestation, soil erosion, nutrient mining, water depletion, soil/water/air pollution, biodiversity loss, and climate change; all of which threaten the long-term viability of agriculture and agro-ecosystems (Cassman et al. 2003; Keating et al. 2010; Phalan et al. 2011; Pretty et al. 2011; Tilman et al. 2011; Chartres and Noble 2015).

This paper reviews the current body of knowledge on a broad suite of crop x environment interactions, including both the constraints on crops imposed by the environment and the impacts of crop production systems on the environment. We focus on key food crops in smallholder production systems in Sub-Saharan Africa and South Asia, including rice, maize, sorghum/millets, sweetpotato/yam, and cassava. We summarize environmental constraints on crop yields (including poor soils, water scarcity, crop pests and disease) and impacts of crop production on the environment (such as soil erosion, water depletion, pollution and pest resistance) at three stages of the crop value chain (pre-production, during crop production, and post-production). Constraints and impacts are then reviewed separately for each crop and region, using publication analysis to assess the relative severity of crop $\mathrm{x}$ environment interactions and the quantity of recent research on crop environmental impacts as reflected in the published literature since 2000. Future areas of potentially high value study are suggested given the importance of the crop, the intensity of the crop $\mathrm{x}$ environment relationship, and the depth of what we currently know and do not know in the literature to date. We conclude with an overview of good practices from the literature and from expert experience for overcoming environmental constraints and minimizing negative environmental impacts in smallholder crop production across regions and farming systems.

By synthesizing the available evidence across these important crops, and emphasizing the feedback loops inherent in agro-ecological systems, we seek to provide a framework for stimulating across-crop discussions and informed debates on a range of crop x environment interactions in agricultural development initiatives. This work can help research planners, policy makers and funding agents have a better understanding of environmental constraints and impacts associated with food crop production practices, and a better appreciation of established good practices to overcome constraints and mitigate impacts.

\section{Materials and methods}

\section{Systematic review of crop $\mathrm{x}$ environment interactions}

Drawing on the academic literature and the field expertise of crop scientists we reviewed how environmental factors constrain the production of important food crops (rice, maize, sorghum/millets, sweetpotato/yam, and cassava) in SubSaharan Africa and South Asia and how, in turn, their cropping impacts on the environment. ${ }^{1}$

As an organizing principle we adopted a value chain approach (Gómez et al. 2011), highlighting key types of environmental constraints and impacts at three stages of the food crop value chain:

- Pre-production, including site/field selection, land clearing, soil tilling, and other land preparation for planting;

- Production, including natural and synthetic inputs for crop production (nutrients, water, agro-chemicals) and the consequences of nutrient and water management and pest control strategies; and

- Post-production, such as crop residues and other waste disposal, and waste and/or pollution attributable to crop transport, processing and storage.

Peer-reviewed published literature was obtained through searches of the Scopus academic database, through supplemental searches of published and grey literature in Google Scholar, and from a range of institutional sources including international agricultural research centers, U.N. agencies and the World Bank.

Additionally, using publication analysis (John and Fielding 2014) we undertook a semi-quantitative assessment of the severity of crop $\mathrm{x}$ environment interactions and the amount of published research, using results from a systematic Scopus search of literature published since 2000 covering a wide range of categories of environmental constraints and environmental impacts. Good practices to manage constraints and reduce the impacts of these crop systems on the environment were also systematically assessed and summarized.

\footnotetext{
${ }^{1}$ This research began as a series of Agriculture-Environment briefs on important food crops in Sub-Saharan Africa and South Asia, produced by the Evans School Policy Analysis and Research Group (EPAR) for the Agricultural Development Group at the Bill and Melinda Gates Foundation. They covered rice (Brief No. 208), maize (No. 218), sorghum/millets (No. 213), sweet potato/yam (No. 225), and cassava (No. 228).
} 


\section{Knowledge assessment of crop $x$ environment interactions}

There is a large but variable body of knowledge in the peerreviewed literature about the many biotic and abiotic constraints on crop yields, and an increasing amount known about how agriculture affects the environment. We evaluated the relative importance of crop $\mathrm{x}$ environment interactions by assessing (i) the frequency with which an environmental constraint to crop production, or environmental impact from crop production, is mentioned in the peer-reviewed literature, and (ii) whether it is characterized in that literature as minor, moderate or severe. This accounting depends on the stock of literature, so we also assessed the amount of research (number of published papers) on these environmental topics for each crop in each region. This helped us to identify apparent gaps in research on crop $\mathrm{x}$ environment interactions.

Three criteria were used to summarize the recent evidence currently available in peer-reviewed scholarship:

- Severity of environmental constraints reported. We summarized, for six general categories, the relative significance of various environmental constraints on crop production based on a comprehensive review of published literature and consultation with crop experts. The categories include land availability, nutrient constraints, water constraints, biotic constraints, climate change, and postharvest losses.

We assessed the severity of these categories of environmental constraints for each crop on a 5-point scale as follows:

0. No mentions of the environmental constraint in published literature or expert accounts on the crop

1. Rarely mentioned or a minor constraint

2. Sometimes mentioned as a moderate constraint

3. Consistently mentioned as a moderate constraint

4. Sometimes mentioned as a severe constraint

5. Consistently mentioned in published literature or expert accounts on the crop as a severe constraint.

Initial assessments were made by the senior author and then small panels of 2-4 researchers (the authors, plus 1 or 2 scientists with crop-specific expertise) validated or modified the categorizations. The resultant categorization indicates the relative importance, in very broad terms, of different environmental constraints on crop yields.

- Severity of environmental impacts reported. Precise estimates of crop-specific environmental impacts are rarely available. However based on the published literature and expert opinion some assessments of the relative severity of different environmental impacts could be made. Thirteen major categories of environmental impact were identified from the detailed crop-based reviews of literature: land degradation, wild biodiversity loss, agro-biodiversity loss, water depletion, water pollution, soil nutrient depletion, soil pollution, pest resistance, methane $\left(\mathrm{CH}_{4}\right)$ greenhouse gas $(\mathrm{GHG})$ emissions, nitrous oxide $\left(\mathrm{N}_{2} \mathrm{O}\right)$ GHG emissions, air pollution (largely relating to burning), storage chemical contamination, and post-harvest losses.

We classified the severity of crop environmental impacts as:

0. No mentions of the environmental impact in published literature or expert accounts on the crop

1. Rarely mentioned or a minor impact

2. Sometimes mentioned as a moderate impact

3. Consistently mentioned as a moderate impact

4. Sometimes mentioned as a severe impact

5. Consistently mentioned in published literature or expert accounts on the crop as a severe impact.

Assessments of impacts were similarly made by the authors and small panels as described for constraints, though with more difficulty as while 'yield gaps' and 'percentage losses' represent useful accepted measures of the severity of environmental constraints on crop yields (Waddington et al. 2010; van Ittersum et al. 2013), there are no such established methods for evaluating the environmental impacts of crop production. Nevertheless, our categorization provides some indication of the relative importance of different environmental impacts both within crops and across different crops and systems as judged by the academic and expert communities to date.

The assessment of the severity of crop $\mathrm{x}$ environment interactions also depends on how much we know about the issues, i.e., how much research has been completed on a particular problem, which was assessed by our third criterion.

- Depth of research on crop x environment impacts. We conducted a comprehensive series of searches in the Scopus academic database for peer-reviewed articles published between 2000 and 2014 on the 13 categories of environmental impact for each crop and region. Appropriate sets of terms were constructed for the searches in consultation with crop experts and the search information compiled in spreadsheets. Counts of peerreviewed articles published on the various aspects of environmental interactions were then generated for the different crops and regions. These provide quantitative information on the degree to which environmental problems have received attention in recent scholarly debates.

The number of environmental studies retrieved through our Scopus searches is highly uneven across crops, across environmental impacts, and across regions and continents. The quality and depth of studies conducted also varies by crop 
and region. In an attempt to ensure only quality papers were included in the counts (but still enable under-researched crops such as sweetpotato and cassava to be well represented), we eliminated all papers published before 2013 that Scopus reported had been cited fewer than two times. We also report papers cited only 2-4 times separately from more extensively cited papers (with 5 or more citations since their publication). Finally, as the quality of very recent publications may not yet be reflected in citation counts, all papers published in 20132014 with $0-1$ citations to date are reported independently as "new publications."

\section{Crop $x$ environment interactions through the value chain}

\section{Pre-production}

For all food crops, farming decisions (including the choice of crop or variety to plant, the types and amounts of inputs and their management) are directly shaped by the availability and quality of cropland. In areas where land suitable for crop production remains relatively abundant such as in much of Sub-Saharan Africa - the dominant response to land constraints continues to be conversion of forests, grasslands and other non-agricultural land to crops. In South Asia, where land is now relatively scarce, farmers have primarily responded to land constraints through a process of intensification, involving multiple cropping during the year, typically facilitated by the adoption of irrigation, mechanization, organic and synthetic fertilizers, and pesticides. In both cases - whether expanding agricultural production onto new land, or intensifying agricultural production on existing cropland - cropping decisions have direct and often significant impacts on land cover, soil structure and soil nutrients, as well as implications for on-farm and off-farm biodiversity (Stevenson et al. 2014).

Key environmental impacts from agricultural expansion and intensification broadly include:

- Land degradation and erosion: Land clearing exposes land to physical and chemical degradation, as well as contributing to air pollution. Over-cultivation and tillage of degraded and marginal lands damages soil structure, drives soil loss through erosion processes and reduces water retention capacity (e.g., Fowler and Rockström 2001; Hobbs et al. 2008). Loss of vegetative cover also worsens wind and water erosion on sloping uplands (Bai et al. 2008). Land clearing and tillage may also have environmental impacts in the form of fossil fuel use for machinery, or forage/feed production and GHG emissions associated with draft animals.
- Loss of wild biodiversity, both off-farm and on-farm: Cropland expansion, cropping intensification and repeated plantings can negatively affect wild biodiversity directly (e.g., removal of tropical forests, habitat loss, or pesticides killing non-target organisms), as well as indirectly (by disrupting breeding cycles and destroying habitats of sensitive species) (Phalan et al. 2011).

- Loss of food crop genetic diversity: Shifts to moreintensive farming systems often reduce the number of crop species in agro-ecosystems (e.g., by removing trees or intercrops from farm fields). Replacement of multiple locally-adapted and genetically diverse crop landraces or varieties with a smaller number of modern varieties also reduces local and regional agro-biodiversity; in some cases increasing vulnerability to drought, pest infestations and other abiotic or biotic threats (Altieri and Nicholls 2004; Snapp et al. 2010).

- Climate change and air pollution: GHG emissions (such as $\mathrm{CO}_{2}, \mathrm{CH}_{4}$ and $\mathrm{N}_{2} \mathrm{O}$ ) from crop fields tend to increase with increased cropping intensity, and when forests/ grasslands are converted to food cropping. $\mathrm{CO}_{2}$ emissions arise primarily from land conversion (releasing $\mathrm{C}$ stored in forests), soil tillage (releasing soil C) and burning of fields and crop residues which releases both GHGs and particulate air pollution. Other major GHG sources are more crop- or system-specific: $\mathrm{CH}_{4}$ emissions are primarily associated with flooded rice fields, and $\mathrm{N}_{2} \mathrm{O}$ emissions arise from $\mathrm{N}$ fertilizer application (Reay et al. 2012).

The environmental and productivity-related impacts of land-use decisions are not only direct, but also systemic and cyclical in nature. For example, in addition to the intrinsic lost value of wild biodiversity, impacts stemming from land-use decisions may also inhibit provision of valuable ecosystem services such as pollination and pest control, with implications for future crop production (Bommarco et al. 2013). Similarly, climate change, though far less controllable by individual farmers, has impacts on both the global environment and on future local crop production in some specific regions (Burke et al. 2009). Consequently, interventions directed at minimizing or eliminating the environmental impacts of cropping preproduction can have positive implications throughout current and future crop production cycles and in locations far from their origin.

\section{Production}

Once crops have been selected and planted, various environmental factors (including inadequate access to and use of soil nutrients, water shortages and drought, and direct damage from pests, weeds and diseases) can substantially compromise production in both Sub-Saharan Africa and South Asia. At the same time, common responses to these production constraints 
such as applying chemical fertilizers, water extraction and irrigation, and applying pesticides and herbicides often themselves pose significant environmental risks and costs for crops, wildlife and human populations.

Key environmental impacts from crop production practices include:

- Soil nutrient depletion ("nutrient mining"): Nutrient mining occurs when cropped soils experience negative nutrient balances, with extraction losses occurring faster than the replacement of nutrients (Cobo et al. 2010). Effects may be especially severe when food crops are integrated into intensive repeated sequences and rotations with inadequate nutrient management, as is common in South Asia (Timsina et al. 2010), or when socio-economic circumstances and limited technical options prevent adequate replenishment of nutrients on depleted soils, as in much of Sub-Saharan Africa (Vanlauwe et al. 2010; Shiferaw et al. 2011).

- Soil and water contamination: Excessive applications of synthetic nutrients can accumulate in and acidify soils, and runoff nutrients may accumulate in rivers and lakes and leach into groundwater (Fageria 2011). Already a severe problem in large parts of South Asia, nutrient contamination/accumulation is currently only a local issue in Sub-Saharan Africa (where fertilizer underuse is predominant) but will grow as systems intensify. Overuse of synthetic $\mathrm{N}$ is also a major source of global GHG emissions (associated with fertilizer manufacture and use) (Reay et al. 2012). Meanwhile overuse or improper use of pesticides and other agrochemicals in intensifying systems may threaten human health (via poisoning) and further contaminate soil and water, in addition to being an inefficient use of scarce farm resources (Oluwole and Cheke 2009; Gupta 2012).

- Water depletion: Drought and water shortages represent significant constraints to yields and reduce viable cropping areas (de Fraiture et al. 2010; Li et al. 2011), with climate change effects predicted to increase both the severity of droughts and the area of cropland that is drought-prone (Gregory et al. 2005). Efficient irrigation technologies can address water constraints to a degree, but the shortage and depletion of surface water (especially in Sub-Saharan Africa where irrigation is poorly developed) and groundwater resources (mainly in South Asia where more irrigation systems already exist) are growing problems (Ali et al. 2009; Wada et al. 2010).

- Outbreaks, pest resistance, and new pests and diseases: Pests and diseases are frequent constraints and can be sufficiently devastating for some crops that they severely restrict cropping, as is the case with viral diseases of cassava in parts of East Africa (Legg et al. 2006, 2014; Beed 2014). Application of pesticides and shifts towards pest- and disease-resistant crop varieties have gone hand-inhand with the emergence of resistance in some pests, sometimes resulting in devastating outbreaks (Oerke 2006). In other cases, efforts to address crop production constraints have inadvertently introduced new pest and disease problems - for example, the development and use of early-maturing varieties of sorghum and millet to overcome drought constraints has exposed grains to fungi and molds that now devastate harvests in some regions (Haussmann et al. 2012).

As with pre-production decisions, the environmental and productivity-related impacts of crop management and inputuse practices are both direct and systemic. For example, while synthetic $\mathrm{N}$ will often increase crop production, particularly in the many nutrient-depleted farms of Sub-Saharan Africa, the efficiency with which crops are able to convert synthetic N fertilizers to increased production hinges upon the availability of micronutrients and water (often environmentally determined). In the absence of these other inputs, the addition of large amounts of synthetic $\mathrm{N}$ will not be cost-effective for farmers, and may further exacerbate other environmental constraints such as soil acidification or contamination of water supplies with implications for current and future farm production and livelihoods.

\section{Post-production}

Noteworthy crop- or system-specific environmental impacts in post-production include the introduction of environmental or human health toxins in crop storage (either from storage chemicals, or from contaminants of bitoic origin such as aflatoxin (Gnonlonfin et al. 2013), as well as the emission of GHGs from the burning of crop residues (Andreae and Merlet 2001; Lal 2005; Smith et al. 2008). Burning harms local air quality and contributes to respiratory ailments, as well as depleting soil organic $\mathrm{C}$ that could otherwise be used to stabilize soil structure, maintain soil fertility and raise the water-holding capacity of soils.

Cereal crops such as maize also suffer significant losses in traditional storage from various pests and diseases (Tefera 2012), while inadequate harvest, storage and processing methods are major problems leading to high rates of postharvest spoilage among root and tuber crops such as cassava and sweetpotato (Lebot 2009). This lost production equates to not only wasted effort by farmers, but also wasted land clearing (in extensive cropping systems) and wasted agro-chemical application (in more intensive systems) for the production of food that will never be eaten. In other words, post-harvest losses of crops carry the burden of all resources consumed in producing the harvest that is lost. Reducing post-harvest losses from poor processing or storage pests thus both 
a Articles on crop $x$ environment interactions since 2000 by stage in the crop value chain

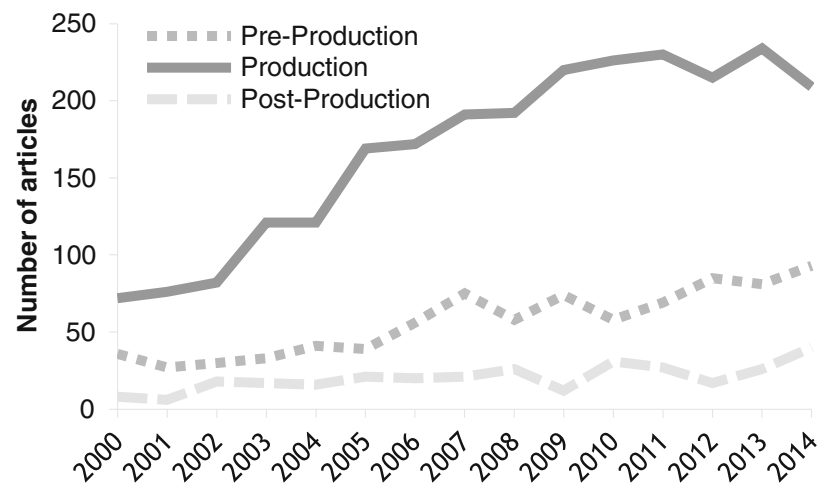

b Articles on crop x environment interactions since 2000 by crop and region

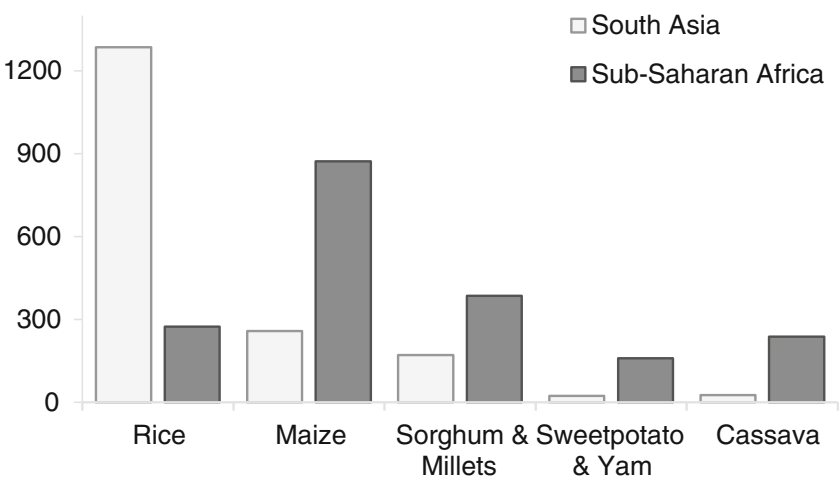

Fig. 1 a-b Number of research articles published between 2000 and 2014 across 13 environmental categories at three stages of the value chain (1a) and by crop and region (1b) for major food crops in Sub-Saharan Africa and South Asia

increases food availability and reduces the per-unit weight or per-unit area environmental impact of a given crop harvest.

\section{Current understanding of crop $x$ environment interactions by crop and region}

While the many environmentally-determined biotic and abiotic constraints have long been a mainstay of the agricultural research and development literature, there has been a relatively recent increase in the number of studies examining the environmental and human health implications of food cropping systems (Fig. 1a). We identified 3694 articles published since 2000 that address crop x environment interactions in some form for at least one of our five focus crops in the two regions (Fig. 1b).

The following sections summarize the current status of published findings on crop $\mathrm{x}$ environment interactions by crop and by region.

\section{Rice crop $\mathrm{x}$ environment interactions}

Rice is the most widely consumed food crop of the developing world, and includes two species (Oryza sativa, native to the Asian continent, and Oryza glaberrima, native to Africa) grown on over 155 million (M) ha worldwide (FAOSTAT 2013). Our assessment of the severity of categories of rice environmental constraints and impacts is summarized in Fig. $2 \mathrm{a}-\mathrm{f}$.

In both the dryland upland rice systems predominant in Sub-Saharan Africa and the irrigated rice systems of South Asia, the single most significant environmental constraint to rice production is water (Fig. $2 \mathrm{a}$ ): rice is $2-10$ times more water intensive than other major crops (Bouman et al. 2007). Other common rice system constraints include inadequate soil nutrients, weeds (in non-flooded systems), insects, rodents and assorted other pests (Waddington et al. 2010; Norton et al. 2010;
Witt et al. 2007), with the shortage of land also a major issue in South Asia (Fig. 2d). Especially in South Asia, agricultural intensification (involving the adoption of modern irrigation, fertilizers, improved seeds, and pesticides) has contributed to dramatic gains in rice yields since the 1960s (Dawe et al. 2010). However, increasing evidence suggests that intensive rice systems, if not properly managed, can cause serious environmental harm by reducing soil fertility, polluting soil and water, depleting groundwater, using large amounts of fossil fuels for water pumping, and contributing to climate change (IRRI 2004). Many of these issues are especially acute for high-yield intensive irrigated winter season rice, which has become very important in parts of South Asia in recent decades (Ali et al. 2009; Barker et al. 2010; Timsina et al. 2010, 2011).

An additional environmental impact unique to flooded rice systems is an increase in insect-borne disease: flooded rice fields have been associated with an increase in malaria transmission among farmers, workers, and communities adjacent to flooded rice-producing areas in both Africa and Asia (Larson et al. 2010).

\section{Sub-Saharan Africa rice systems}

Most smallholder rice production in Sub-Saharan Africa is rainfed, low-input and low-yield upland rice. The overall rice area remains relatively modest in Africa, though recent growth trends have been dramatic: the rice area harvested more than doubled between 1982 and 2012, from 4.9 $\mathrm{M}$ to $10.8 \mathrm{M}$ ha (FAO 2013). Some of this expansion is due to intensification made possible by irrigation and the introduction of Asian sativa varieties into lowland and wetland areas of SubSaharan Africa (this has led to shifts from one to two crops per year, resulting in double-counting of some areas planted to rice) (Larson et al. 2010). But for most smallholders, rainfed rice-fallow systems producing one crop per year remain common (Dawe et al. 2010). Major environmental constraints in the region (Fig. 2a) include water constraints, making up as 
much as $10-31 \%$ of the rice yield gap in Sub-Saharan Africa, nutrient constraints (15-30\% of the yield gap) and weeds, especially where flooding is not an option for weed control (Dobermann and Fairhurst 2000; Waddington et al. 2010).

Relative severity of environmental impacts Africa's largely dryland rice systems are relatively insignificant contributors to environmental impacts typical of more intensive rice systems, such as water resource depletion, $\mathrm{CH}_{4}$ emissions or chemical runoff (Yan et al. 2009). The key environmental threats from extensive low-productivity rice in Sub-Saharan Africa take the form of degradation of fragile and erosion-prone uplands (Bai et al. 2008), or the expansion of new sativa flooded rice production into ecologically important lowland/wetland ecosystems (Rodenburg et al. 2014) (Fig. 2b). The relatively recent introduction of formal irrigation into rice production in Sub-

a Relative Severity of Rice Constraints (SSA)

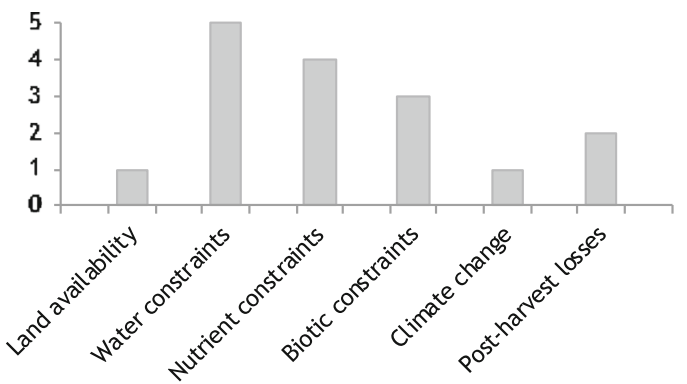

b Relative Severity of Rice Impacts (SSA)

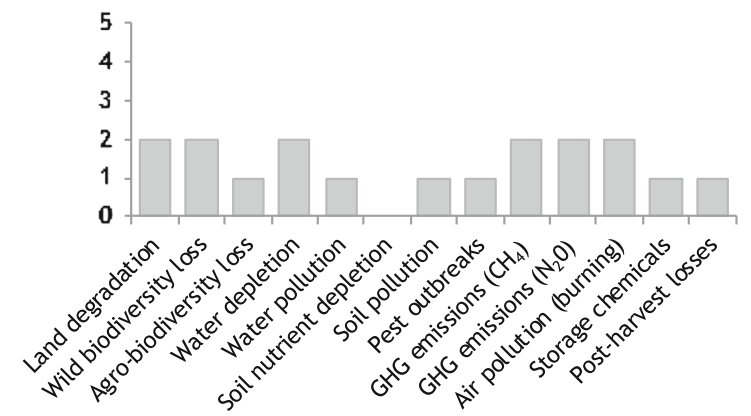

c Research on Rice-Environment Interactions (SSA)

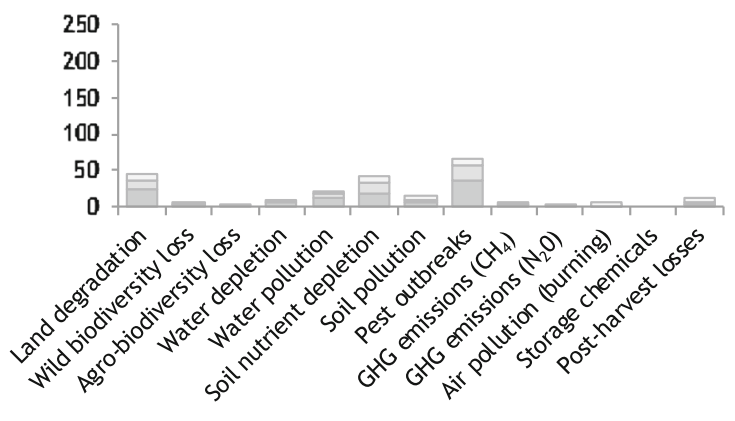

$\square>5$ citations since 2000

$\square$ 2-4 citations since 2000

f Research on Rice -Environment Interactions (SA)

$\square$ New publication (2013-2014)

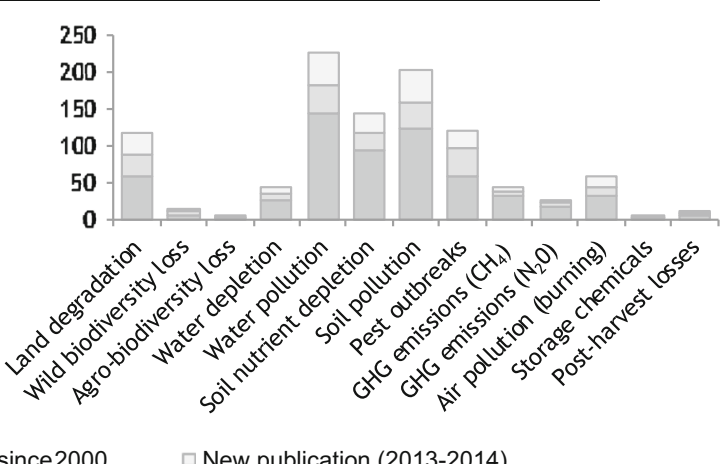

Saharan Africa has been linked to dramatic increases in rice productivity - in 2009 only $14 \%$ of rice area in the region was irrigated, but this area made up $33 \%$ of total rice produced (Africa Rice Center 2010). Although intensification also entails impacts such as chemical runoff and GHG emissions, such impacts have received little empirical attention in the published scholarship to date.

Research on environmental interactions and areas of debate Overall research on environmental impacts of rice is limited in Sub-Saharan Africa (Fig. 2c). No estimates of impacts such as land conversion or biodiversity loss attributable to upland rice are available, though some research is underway (Phalan et al. 2011). Moreover an expanding body of research surrounding the successes and failings of new NERICA varieties (open-pollinated improved varieties of

d Relative Severity of Rice Constraints (SA)

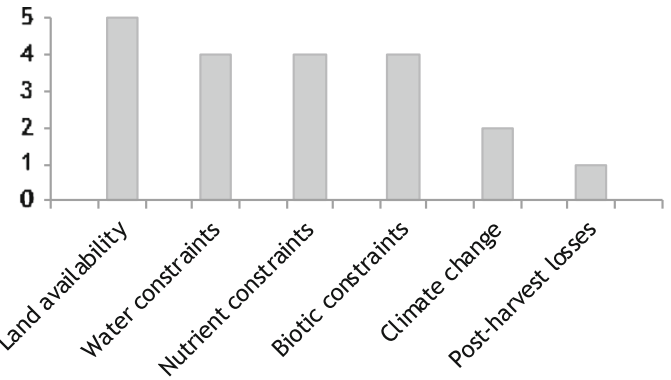

e Relative Severity of Rice Impacts (SA)

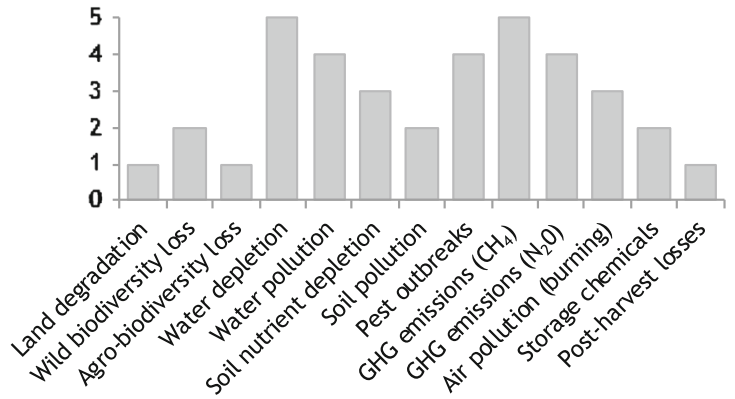

Fig. 2 a-f Relative severity of environmental constraints and impacts, and the depth of environmental research for rice in Sub-Saharan Africa (2a-c) and South Asia (2d-f) 
upland rice) is beginning to identify upland rice constraints and impacts with greater detail (see e.g., Kijima et al. 2011). Research on environmental impacts in new irrigation-based rice systems in Sub-Saharan Africa lags behind research on production, and as there is very limited local information, current reviews of Sub-Saharan Africa rice environmental impacts largely draw on the Asian experience with rice intensification (Larson et al. 2010). Site-specific (and somewhat more contested) studies on improved soil and water management in Sub-Saharan Africa such as the System of Rice Intensification (SRI), which was originally developed in Madagascar (see Dobermann 2004; Uphoff et al. 2008), suggest significant opportunities for increasing yields, water efficiency and pest management in Sub-Saharan Africa.

\section{South Asia rice systems}

In South Asia, smallholder rice is produced principally during the monsoon season under rainfed conditions, but increasingly also under irrigation pre-monsoon. With most of the land suitable for rice already under production, the necessarily intensive South Asia rice systems face several well-known biotic and abiotic constraints (Fig. 2d). Most farmers are reliant upon synthetic fertilizers and pesticides (often at high rates) to maintain yields. Soil nutrient shortages, particularly N, P and K, seriously limit production (Witt et al. 2007; Waddington et al. 2010) while pests including insects, rodents and disease also significantly reduce rice yields (Singleton 2003; Mejia 2004). Water constraints meanwhile are ubiquitous, accounting for as much as $23 \%$ of rice crop losses, including in irrigated rice and rice-wheat systems ( $\mathrm{Li}$ et al. 2011).

Relative severity of environmental impacts Far more published research is available for environmental impacts of South Asian rice production systems as compared to African rice systems (Fig. 1b). Rice production in South Asia has many known environmental impacts, with water depletion and contamination, the evolution of pest resistance and GHG emissions among the most important (Fig. 2e). Many of these environmental impacts are severe and commonly found due to the relatively chemical-intensive and irrigationbased production practices typical of widespread smallholder double-crop South Asian rice production. Irrigation is a key driver of water depletion in South Asia, with $50 \%$ of all irrigation used for rice (Wada et al. 2010). Meanwhile, the overuse of synthetic fertilizer and other chemicals has been linked to runoff and even poisonings, partly owing to input use beyond prescribed levels (Pingali 1995; Peng et al. 2006). Historically, an overuse of insecticides for rice has also reduced populations of pests' natural enemies, leading to pest outbreaks (Heong and Schoenly 1998). Finally, rice systems are estimated to constitute $10 \%$ or more of global annual $\mathrm{CH}_{4}$ emissions, with emissions concentrated in the flooded rice fields of India and China (Yusuf et al. 2012).

Research on environmental interactions and areas of debate There is a wealth of research on the environmental impacts of rice production in South Asia (Fig. 2f), including recent reviews (Pandey et al. 2010). In particular, water and soil pollution related to rice has featured in many recent publications. Rice pre-production (land clearing) is relatively under-studied but also fairly low-impact: as most potential arable land in South Asia has already been converted to agriculture, the new biodiversity and habitat impacts of rice are likely to be small - although the high pressure for continued blanket cropping of rice means it is unlikely that some rice land will be returned to more 'natural' agro-ecosystems. Meanwhile the effects of rice farming on soils and chemical runoff rates vary by system and by crops planted between rice harvests. There is growing consensus on the non-sustainability of intensive premonsoon/winter irrigated rice systems in terms of nutrient demand, agro-chemical use and water management (e.g., Ali et al. 2009; Timsina et al. 2010). Perhaps most visible among these rice-environment interactions is the effect of rice-related water depletion on rice productivity - already the high financial cost (associated with pumps and fuel) of irrigated winter rice production has encouraged farmers on the eastern Gangetic Plain to scale back on this production system. There is also increasing consensus on the significant role of irrigated rice in climate change via $\mathrm{CH}_{4}$ emissions (Yan et al. 2009; Yusuf et al. 2012).

\section{Maize crop x environment interactions}

Globally, maize is an extremely important food crop. The area of maize harvested worldwide increased $69 \%$ between 1961 and 2012, from 106 to $179 \mathrm{M}$ ha (FAOSTAT 2013), accompanied by trends towards intensified maize production systems. During the 20th and into the 21 st century, maize has become the principle food crop produced and consumed by Sub-Saharan Africa smallholder farm households (Shiferaw et al. 2011) and it is an increasingly important smallholder food and cash crop in South Asia (Joshi et al. 2005). This growth stems from a combination of non-agricultural land converted to maize-based agriculture, existing cropland converted to higher-yielding maize, and maize intensification through annual double-harvests from fertilized and irrigated fields. Maize production systems and environmental impacts differ among the regions, as we indicate below.

Maize production has important environmental consequences in both extensive systems (such as habitat loss, soil degradation and GHG emissions from deforestation in Africa) and intensive systems (via nutrient mining and 
a Relative Severity of Maize Constraints (SSA)

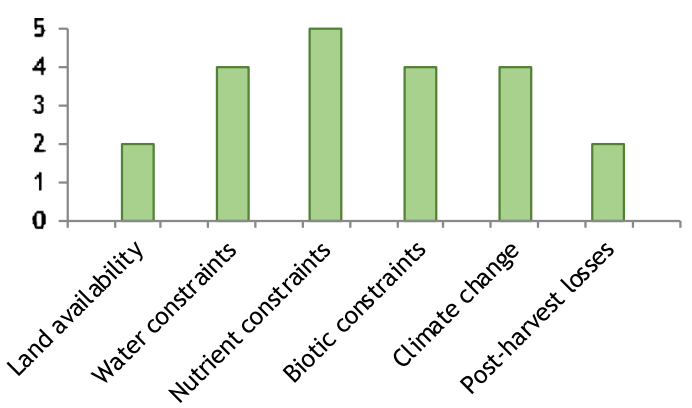

b Relative Severity of Maize Impacts (SSA)

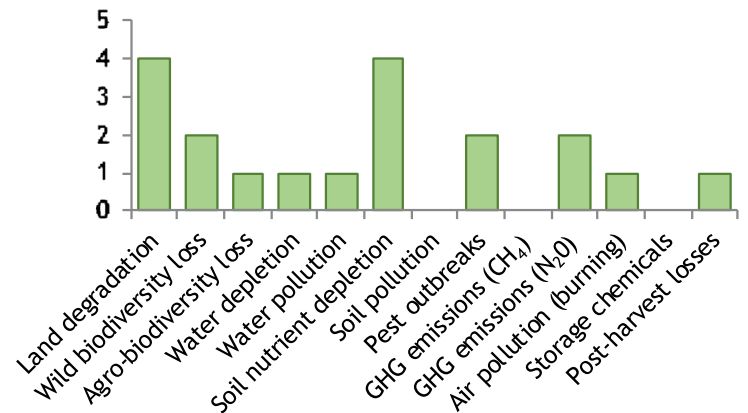

C Research on Maize-Environment Interactions (SSA)

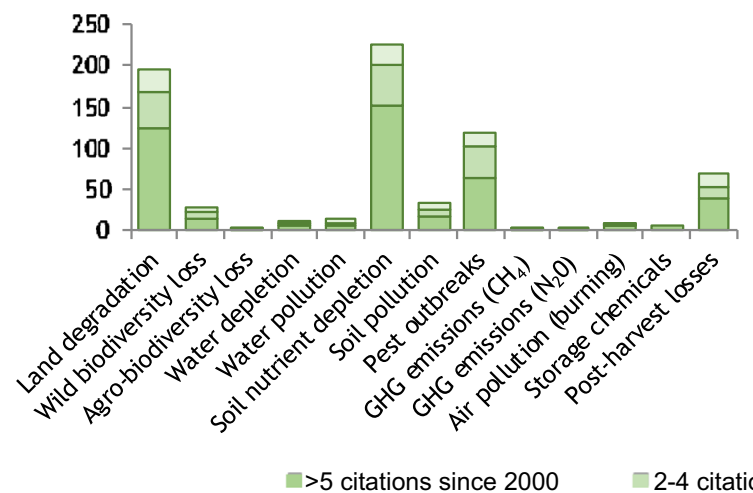

d Relative Severity of Maize Constraints (SA)

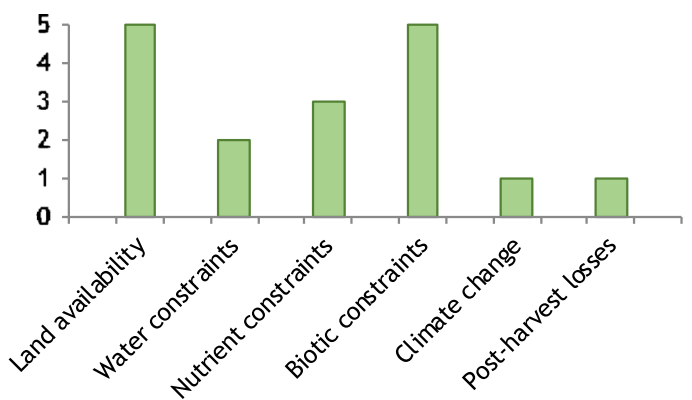

e Relative Severity of Maize Impacts (SA)
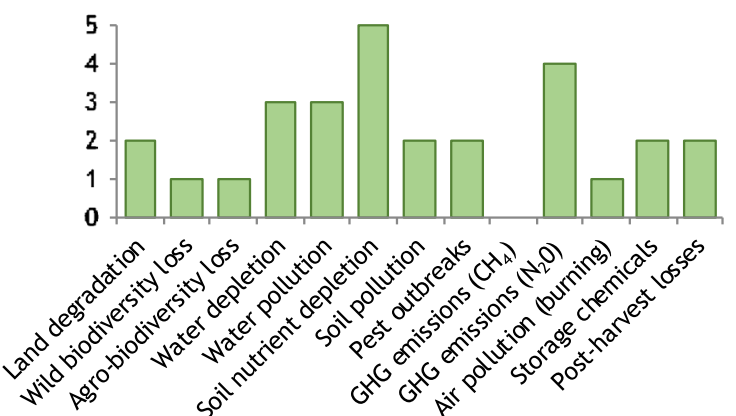

f Research on Maize-Environment Interactions (SA)

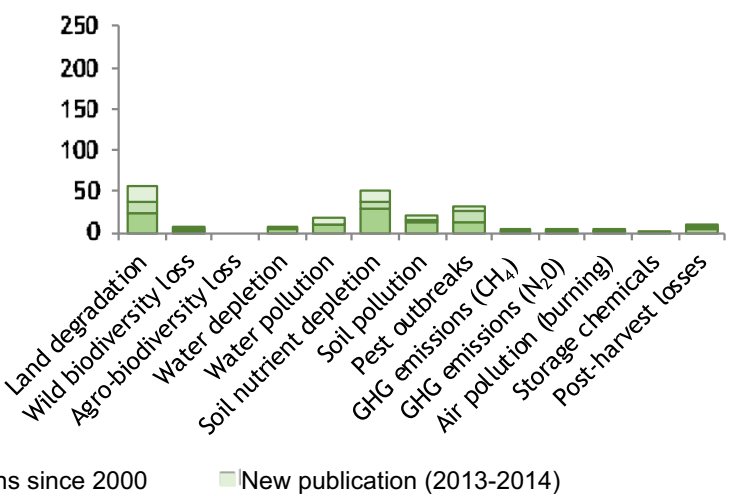

Fig. 3 a-f Relative severity of environmental constraints and impacts, and the depth of environmental research for maize in Sub-Saharan Africa (3a-c) and South Asia (3d-f)

contamination, and pesticide contamination in South Asia) (Fig. 3b, e). The relatively widespread and rising use of synthetic fertilizers in maize systems is also responsible for the release of GHGs, both during manufacture of the fertilizer and in its use (Reay et al. 2012).

\section{Sub-Saharan Africa maize systems}

The area dedicated to maize in Sub-Saharan Africa more than doubled (15.5 to $34.1 \mathrm{M}$ ha) from 1961 to 2012 (FAOSTAT 2013). Maize dominates in southern and eastern Africa, constituting 20 to $50 \%$ of food consumption. In recent decades, maize has also spread in western and central Sub-Saharan
Africa (Shiferaw et al. 2011). The crop is typically grown in Africa as a primary food crop, in rainfed smallholder farming systems, often on marginal soils and/or newly cleared land, and with inadequate or no synthetic inputs.

Soil infertility and nutrient shortages represent the most severe and widespread constraints to maize yields in SubSaharan Africa (Mueller et al. 2012). Drought is also a major constraint (Waddington et al. 1995; Gibbon et al. 2007), with small changes in rainfall patterns/amounts and temperatures leading to appreciable loss of yield (Lobell et al. 2011a). Pests such as downy mildew, grey leaf spot, armyworm, stemborers, and the parasitic weed Striga spp. also hamper production (Pingali and Pandey 2000). Pests also damage maize post- 
harvest, with losses in Africa estimated by the World Bank (2011) to be $10-20 \%$ of production (Fig. 3a).

Relative severity of environmental impacts The environmental impacts of maize cropping in Sub-Saharan Africa largely relate to land clearing and degradation, soil erosion, nutrient depletion and biodiversity loss (Fig. 3b). Because maize is so widely grown in Africa, these effects are widely seen. Maize is a common first crop after slash and burn clearing as farmers value its ability to utilize nutrients released by the burning to boost yields (Binam et al. 2004). Deforestation destroys wildlife habitat and releases GHGs (Fargione et al. 2008), with maize-related clearing continuing in several large African countries including Nigeria, Ethiopia and Sudan (Phalan et al. 2013). Efforts to improve soil management (through minimal tillage, residue retention and intercropping) can reduce soil erosion and nutrient losses, but adoption of conservation agriculture techniques in Sub-Saharan Africa remains limited (Bossio et al. 2010; Erenstein et al. 2012). Other impacts such as nutrient and chemical contamination are only localized in much of Africa; in most areas fertilizers and pesticides are generally underused.

\section{Research on environmental interactions and areas of} debate There has been a considerable amount of research on the environmental impacts of maize in Sub-Saharan Africa in recent years (Fig. 1b), with most of the publications covering soil degradation, nutrient depletion and pests (Fig. 3c). Continuous production of maize with limited fertilizer inputs is commonly reported to contribute to the depletion of soil nutrients and soil erosion is common in maize cropping systems, but maize-specific data on land degradation in SubSaharan Africa are only now emerging (Cobo et al. 2010). Moreover, the net effects of maize on land and climate are unclear as higher-yield maize might decrease land clearing compared to reliance on lower-yield traditional cereals. There is near consensus that the impacts of climate change will be severe for rainfed maize in several large parts of the continent such as in southern Africa and the Sahel (Schlenker and Lobell 2010).

\section{South Asia maize systems}

Total maize area harvested in South Asia is less than half that of Sub-Saharan Africa, but the area grew rapidly by $92 \%$ percent from $6.0 \mathrm{M}$ ha in 1961 to $11.5 \mathrm{M}$ ha in 2012 (FAO 2013). Much of the growth reflects a switch from rice, wheat, or dryland cereal crops, and an increase in winter and spring (pre-monsoon) maize (Ali et al. 2009; Joshi et al. 2005). In India and Nepal, farmers have traditionally grown rainfed upland maize during the monsoon season as a supplemental food and income source. Increasingly, maize is also grown as a high-input crop both in the monsoon and with irrigation during the winter season, in sequence with other crops such as monsoon rice, to produce feed for sale to expanding poultry industries (Joshi et al. 2005). Very recently, maize has also become more significant during the spring (premonsoon) season. Thus there are now very large areas with relatively fertile soils and developed irrigation systems planted to intensive maize in South Asia, as well as the more traditional systems (Timsina et al. 2010, 2011).

Constraints to maize in South Asia vary by sub-region. A 2001 survey of farmers in India found post-flowering stalk rot to be the most widespread severe constraint (Gerpacio and Pingali 2007). Soil nutrient deficiencies are also a yield barrier (though less severe than in Africa), reducing output by up to $14 \%$ (Gibbon et al. 2007). Losses from drought are relatively modest and occur mainly in rainfed upland maize systems (which nonetheless support some 48 million rural poor). Post-harvest losses are also generally modest, estimated at 2-15\% of production (Fig. 3d).

Relative severity of environmental impacts South Asian maize is now commonly a high-input crop produced using hybrid seed, irrigation, fertilizer (up to 100-200 kg N/ha), pesticides and herbicides (Ali et al. 2009; Joshi et al. 2005). As with many intensive systems, repeated cultivation and the overuse of synthetic inputs may degrade soils and contaminate soil and water. Pesticides can destroy beneficial species that manage pests; pesticide poisoning and other human health impacts have also been reported (Gupta 2012). Herbicide use risks killing crops that are often intercropped or rotated with maize, including beneficial legumes (Kanampiu et al. 2002). All of this makes soil degradation, water depletion and pollution, nutrient depletion and chemical pollution key impacts (Fig. 3e), though our review found little data specific to maize for the intensive multi-crop systems increasingly typical of South Asia.

Research on environmental interactions and areas of debate Concerns with sustainable soil and nutrient management have emerged recently in South Asian maize systems and are receiving more attention in recent scholarship (Ali et al. 2009; Timsina et al. 2010, 2011), as are climatic factors such as high temperatures. But overall published environmental research specific to maize appears to be very thin in South Asia (Figs. 1b and 3f). As with Africa, the net environmental impacts of maize in South Asia are also somewhat ambiguous - in the face of water constraints and major environmental impacts from intensive rice farming, maize is seen as a relatively high-yield and water-efficient alternative crop for promoting both food production and resource use efficiency in this region (Ali et al. 2009; Timsina et al. 2011). 


\section{Sorghum/millets crop $\mathrm{x}$ environment interactions}

Sorghum and millets (which are a diverse group of small-grain annual cereal grasses including pearl millet, foxtail millet, finger millet and several others) are particularly important for smallholder farmers on marginal lands that are prone to drought. Sorghum and millet production systems and environmental impacts differ vastly across regions. In Sub-Saharan Africa, sorghum and many different millets (though increasingly pearl millet is dominant) are typically grown as the primary food crop in dry rainfed systems on poor soils with minimal synthetic inputs. In contrast, South Asian sorghum and millet crops are increasingly irrigated and higher-input, grown for market sale in sequence and rotation with other crops. In both Sub-Saharan Africa and South Asia, sorghum and especially the millets have suffered from a dearth of empirical research, both on environmental constraints and environmental impacts (Fig. 1b). Our assessment of the relative severity of a range of environmental constraints and impacts for sorghum and millets is given in Fig. $4 \mathrm{a}-\mathrm{b}$ and d-e.

Sorghum and some millets are tolerant of low soil fertility and drought in comparison to other cereals, and so are widely grown in areas with unreliable rainfall and few inputs in Sub-Saharan Africa and parts of South Asia (Garí 2002; Waddington et al. 2010), often on ecologicallyfragile land (Tari et al. 2013). Shortened fallows and expansion onto marginal lands with little use of fertilizer has led to declining soil fertility and yields on sorghum/millet plots (Clay 2004). Though relatively drought-tolerant, these crops still yield far less under drought conditions (Waddington et al. 2010; Mutava et al. 2011). As the rainfall season is frequently short and intense in sorghum and millet growing regions and soil cover sparse, problems such as waterlogging, water runoff and soil erosion represent major yield constraints (Witcombe and Beckerman 1987; Murty et al. 2007). Low temperatures, low soil P, Fe toxicity, acid soils, and wind damage (blown sand) also hinder crop yields, while downy mildew, insect pests, and weeds such as Striga cause severe losses (Michels et al. 1993; Jeger et al. 1998; Clay 2004; Singh et al. 2009; Tari et al. 2013).

\section{Sub-Saharan Africa sorghum/millets systems}

In 2012, sorghum and millets together accounted for $40 \%$ of the cereal area harvested and $23 \%$ of cereal production in Sub-Saharan Africa (FAOSTAT 2013). Sorghum is the more commonly grown of the two cereals, and its area harvested in Sub-Saharan Africa increased by $72 \%$ from 1982 to 2012, with the former Sudan and Nigeria making up much of the new area (FAOSTAT 2013). Millets represent $10 \%$ of the area harvested for all crops in Sub-Saharan Africa, and are especially important for smallholder farmers on droughtprone marginal lands.

Sorghum and millets are often low yielding $(<500 \mathrm{~kg} / \mathrm{ha})$ due to genetic and environmental factors (Ahmed et al. 2000), and frequently yield far less than the common alternative of maize in many sub-humid smallholder systems in Sub-Saharan Africa (e.g., Rurinda et al. 2014). Nevertheless, locally adapted varieties remain very important for food security - pearl millet, finger millet and "minor millets" like fonio or tef are often planted on the most marginal lands where maize and even sorghum fail (Mohamed et al. 2002). Sorghum and millet cultivation is expected to expand in Sub-Saharan Africa as an adaptation to climate change (Cooper et al. 2008; Sultan et al. 2013).

Relative severity of environmental impacts The environmental impacts of sorghum and millets in Sub-Saharan Africa largely relate to land clearing and degradation (including nutrient depletion) on marginal soils (Fig. 4b). The overall environmental impacts of sorghum and millet cultivation are generally considered less severe than other major crops owing to the sparse and low-input nature of production. However the crops' adaptability to marginal soils can lead to planting on nutrient-depleted soils and sloped and erosion-prone fields that would otherwise be left undisturbed, contributing to a loss of soil and biodiversity. On-farm biodiversity is also decreasing - while historically smallholders planted multiple local species and varieties of millets (and sorghum) with different agronomic and nutritional attributes, and end uses, pearl millet now makes up $90 \%$ of the millet grown in Sub-Saharan Africa (Haussmann et al. 2012).

Additionally, the use of sorghum and millet residues for fodder, fuel and construction has become widespread. Although the integration of sorghum crop residues into soils is widely recommended for increasing soil fertility and moisture retention on fields, and to reduce $\mathrm{CO}_{2}$ emissions (Valbuena et al. 2012), this deprives farmers of valuable fodder, fuel, and incomes from stover. The removal of crop residues further exposes soils to wind and water erosion, depletes soil nutrients for future crops and contributes to air pollution. In such situations, increased judicious use of agricultural inputs (including fertilizers) may reduce environmental impacts by increasing the productivity of grain and stover, and slowing the damaging expansion of agricultural land.

Research on environmental interactions and areas of debate The overall literature on environmental impacts of sorghum and millets in Sub-Saharan Africa is thin (Fig. 4a). The impacts of sorghum/millets on soils in Sub-Saharan Africa have only recently begun to be studied (Subbarao et al. 2000; Fageria 2011) while little is known about climate change, weeds, and pests with these crops. Research is also minimal on disease, post-harvest losses, biodiversity loss, and GHG emissions. Research and discussion may be hindered in 
a Relative Severity of Sorghum/Millet Constraints (SSA)

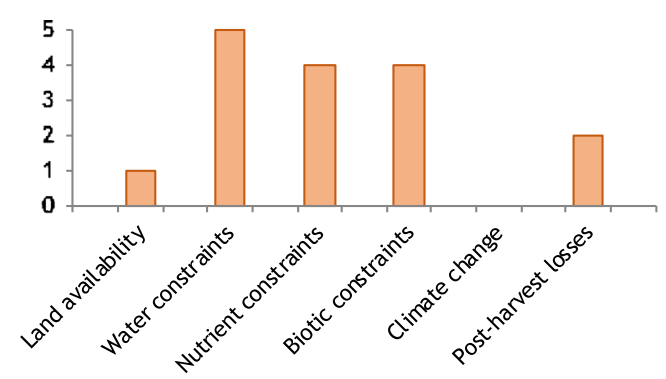

b Relative Severity of Sorghum/Millet Impacts (SSA)

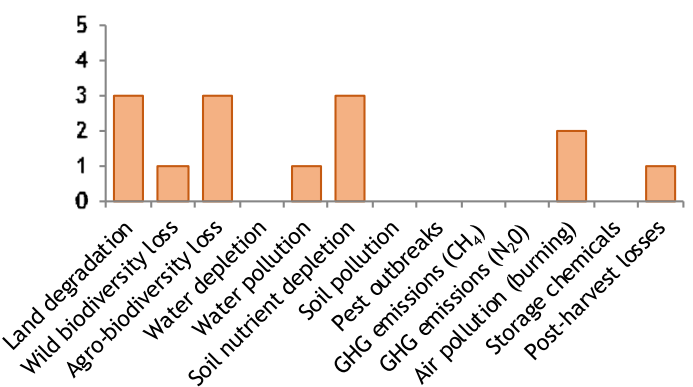

C Research on Sorghum/Millet-Environment Interactions (SSA)

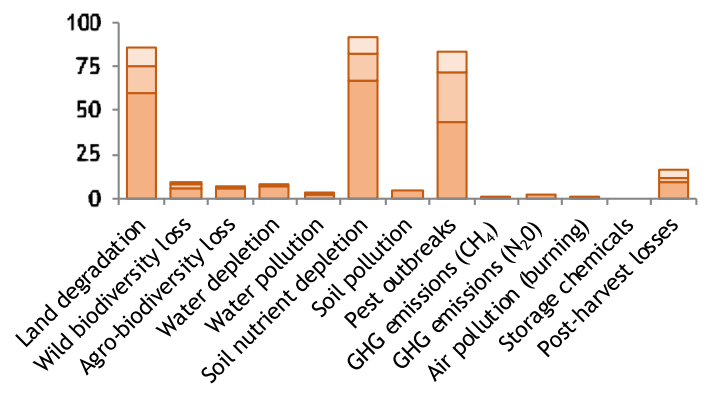

d Relative Severity of Sorghum/Millet Constraints (SA)

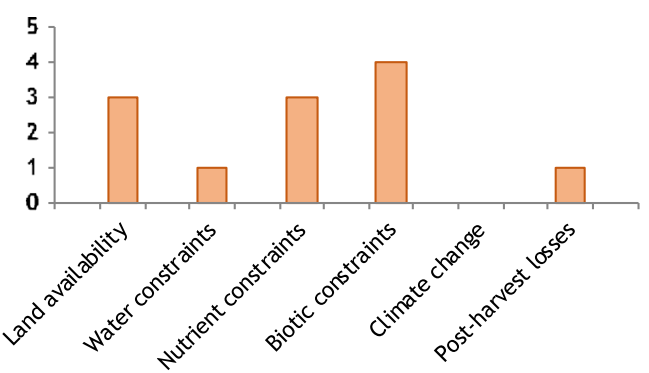

e Relative Severity of Sorghum/Millet Impacts (SA)

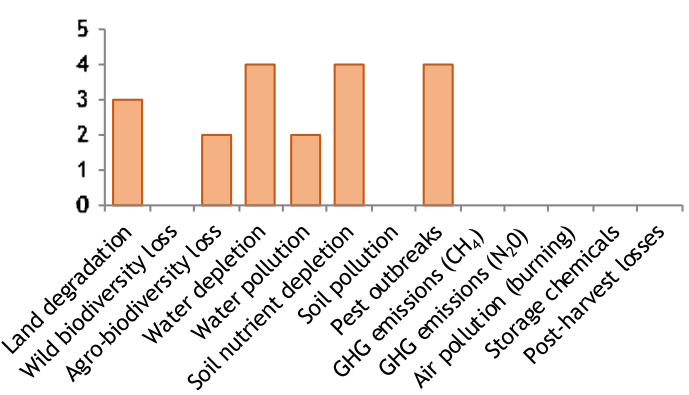

f Research on Sorghum/Millet-Environment Interactions $\underline{(S A)}$

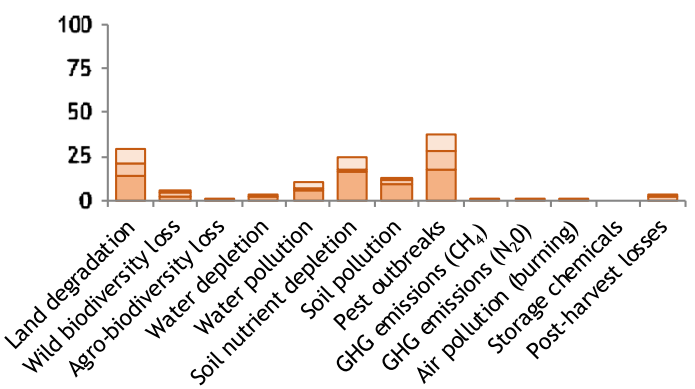

>5 citations since $2000 \quad$ 2-4 citations since $2000 \quad$ New publication (2013-2014)

Fig. 4 a-f Relative severity of environmental constraints and impacts, and the depth of environmental research for sorghum and millets in Sub-Saharan Africa $(4 \mathrm{a}-\mathrm{c})$ and South Asia $(4 \mathrm{~d}-\mathrm{f})$

part by the many species classified as millets, and by the range of (often harsh and remote) sorghum and millet growing environments that present challenges for researchers.

\section{South Asia sorghum/millets systems}

In 2013, sorghum and millets accounted for $12 \%$ of the cereal area harvested and just $4 \%$ of cereal production in South Asia (FAOSTAT 2013). The area planted with sorghum or millets has declined steeply since 1980 , but average yields have remained steady or increased owing to the adoption of improved varieties and more-intensive cultivation practices (Basavaraj et al. 2010). Sorghum and millets in South Asia are typically grown for grain and fodder as dryland non-irrigated crops, often in rotation with pulses or oilseeds. Smallholders in southern India grow sorghum and four types of millet (pearl millet, finger millet, little millet, and foxtail millet) in diverse combinations depending on local preferences and ecologies. In some parts of South Asia, sorghum and pearl millet are increasingly irrigated, especially to raise fodder production (Basavaraj et al. 2010).

Relative severity of environmental impacts With recent trends to intensify production (Pray and Nagarajan 2009), sorghum and millet systems in South Asia exhibit some of the adverse environmental impacts of other intensive crop systems, such as soil degradation, nutrient mining, water depletion and agro-chemical runoff (Fig. 4e). Irrigation of sorghum and pearl millet threatens already scarce water resources in South Asia (García-Ponce et al. 2013). The emergence of new pest and pathogen strains is another major concern in this region. In the past, use of early-flowering varieties of pearl millet (bred to overcome drought constraints) also exposed the 
developing grain to wet conditions in which grain molds thrive (Williams and Rao 1981).

Research on environmental interactions and areas of debate Sorghum and millet production impacts in South Asia are rarely studied alone, but are usually treated in the literature on the multi-crop systems of which they are a part. The volume of research on environmental impacts of sorghum is only slightly more than that of millets in South Asia. Water constraints and drought, and soil nutrient limitations are commonly considered to be important with sorghum and millets in this region, but the roles of climate change, weeds, and pests are less clear (Fig. 4b). There appears to be very little published on diseases, post-harvest impacts, biodiversity loss, and GHG emissions associated with sorghum and millet smallholder cropping. Overall, however, while these crops have long been considered minimally damaging to the environment, recent research emphasizes the contributions of intensively cultivated sorghum and millets to the broader soil and water problems that threaten South Asia's intensifying food cropping systems.

\section{Sweetpotato and yam crop $x$ environment interactions}

Root and tuber crops (including sweetpotato, yams, and cassava) represent (after cereals) the second-most cultivated group of food crops in tropical countries (FAOSTAT 2012). Yam is almost exclusively grown in Sub-Saharan Africa rather than in South Asia, while sweetpotato is favored in both regions because of its low labour needs, low input costs and relatively low production risk (Low et al. 2009). Additionally, sweetpotato is tolerant of diverse growing conditions (Edison et al. 2009), providing good yields even with poor soils, extreme temperatures and prolonged dry seasons (Paeth et al. 2008; Claessens et al. 2010; Kyamanywa et al. 2011; Thornton 2012; Bagamba et al. 2012).

Sweetpotato and yam are low-input crops - and are regularly grown without inputs (Andrade et al. 2009) - although some chemical pesticides are increasingly used to address major pests and diseases such as sweetpotato weevil and the insect-borne yam mosaic virus. When grown using traditional methods, sweetpotato and yam are considered to have few negative environmental impacts relative to most cereal crops. Both plants are easily intercropped (or grown in soil mounds for home gardens), and their fast growth and dense foliage help reduce soil erosion (ASARECA 2005). Figure 5 provides our assessment of the severity of sweetpotato and yam environmental constraints and impacts.

\section{Sub-Saharan Africa sweetpotato and yam systems}

East and West Africa account for $93 \%$ of the African sweetpotato area, with intensive production around Lake
Victoria (CIP 2010). For yam, West Africa contains $90 \%$ of the global area planted and $90 \%$ of global harvests (CIP 2010). Sweetpotato and yam in Sub-Saharan Africa are often secondary crops grown by female smallholders in polyculture systems on small marginal plots (Low et al. 2009; Andrade et al. 2009; Ewell 2011). In addition to cropped fields, sweetpotato is widely found on patches of mounded/ridged land near homesteads or in gardens.

Yield constraints for sweetpotato and yam in Sub-Saharan Africa include drought, disease, and soil infertility. In a survey of farmers in East Africa, drought was considered the largest production constraint to sweetpotato (Fuglie 2007). Sweetpotato is also susceptible to viral infections, with over 15 known viruses reported (Valverde et al. 2007). Damage from pests and vegetative propagation using contaminated vine cuttings exacerbate disease risks.

For yam, the infertility of soils is the key constraint in intensive yam-producing areas of West Africa (Lebot 2009). Experiments in Nigeria saw yam yields decrease by $50 \%$ in 5-6 years because of declining soil fertility (Agbaje et al. 2005). Yam is more drought tolerant than sweetpotato (Lebot 2009), but insects and disease seriously reduce yam yields. The yam tuber beetle, scale insects and termites are major pests (Lebot 2009); nematodes (Agbaje et al. 2005) and mealybugs (Peters 2000) are also threats. Anthracnose and yam mosaic virus are significant yam diseases (Peters 2000; Amusa et al. 2003).

Relative severity of environmental impacts More research is available for environmental impacts of Sub-Saharan Africa sweetpotato/yam production systems compared with those in South Asia (Fig. 5ab). Although sweetpotato and yam are usually considered relatively low-impact crops in SubSaharan Africa, both may contribute significantly to agricultural expansion, the loss of biodiversity, and land degradation on marginal cropland where they are regularly grown across large areas in parts of Africa (Fig. 5a). Particularly in the presence of pests or disease, sweetpotato and yam may also experience high crop losses during post-harvest processing and storage, representing potentially significant wasted labor, land, and other resources in production (Fig. 5a). Use of agrochemicals for sweetpotato/yam remains rare in most of SubSaharan Africa (with the notable exception of Nigeria). However pesticide use is growing in some areas (including Uganda).

Research on environmental interactions and areas of debate Pest and disease outbreaks and resistance have attracted major research attention with sweetpotato/yam in Africa (Fig. 5c), with some work on soil degradation, nutrient depletion, and post-harvest loss, but little published in other areas. Some research indicates sweetpotato and yam may be relatively resilient to climate change, but other work 
a Relative Severity of Sweetpotato/Yam Constraints (SSA)

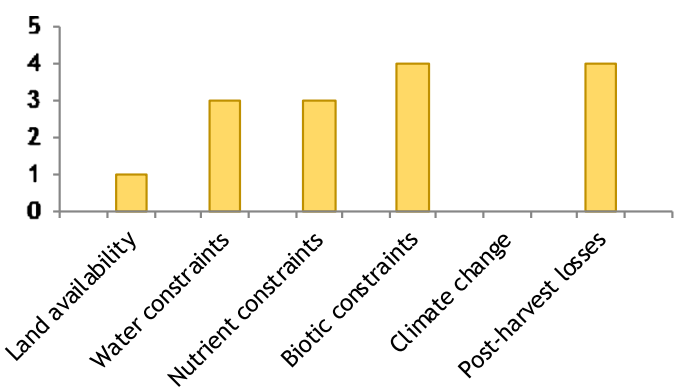

b Relative Severity of Sweetpotato/Yam Impacts (SSA)

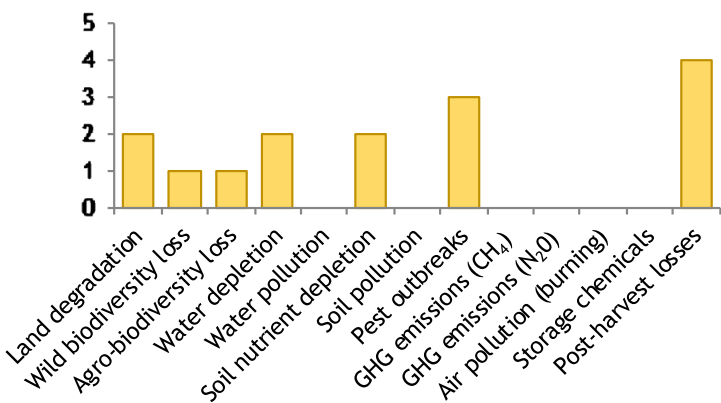

C Research on Sweetpotato/Yam-Environment Interactions (SSA)

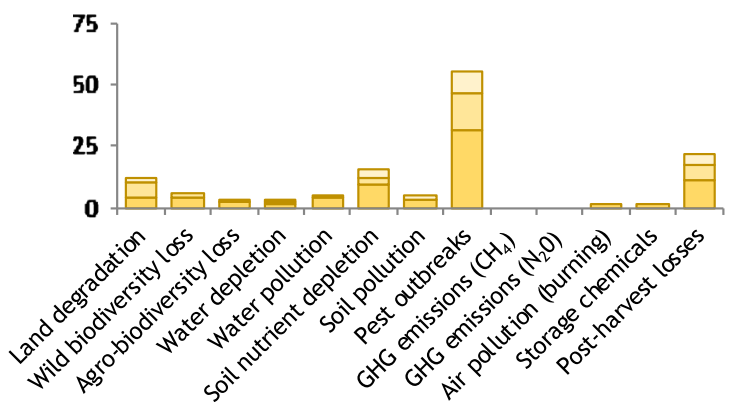

$>5$ citations since 2000 d Relative Severity of Sweetpotato/Yam Constraints (SA)

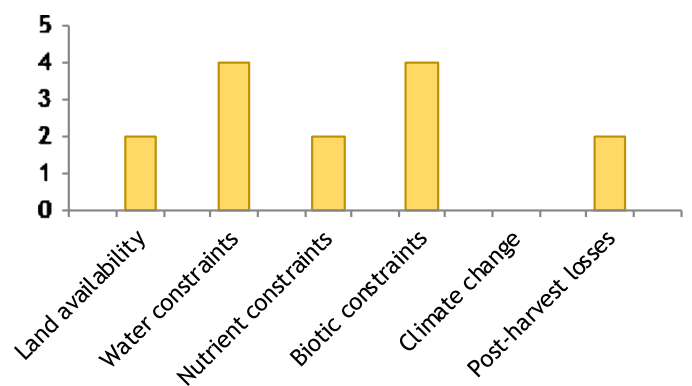

e Relative Severity of Sweetpotato/Yam Impacts (SA)

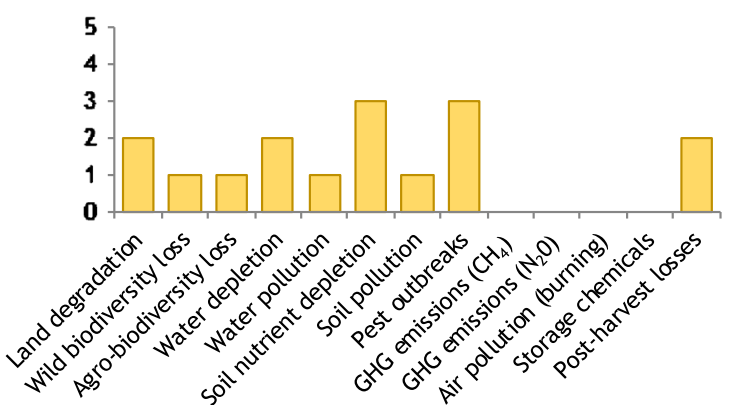

f Research on Sweetpotato/Yam-Environment Interactions (SA)

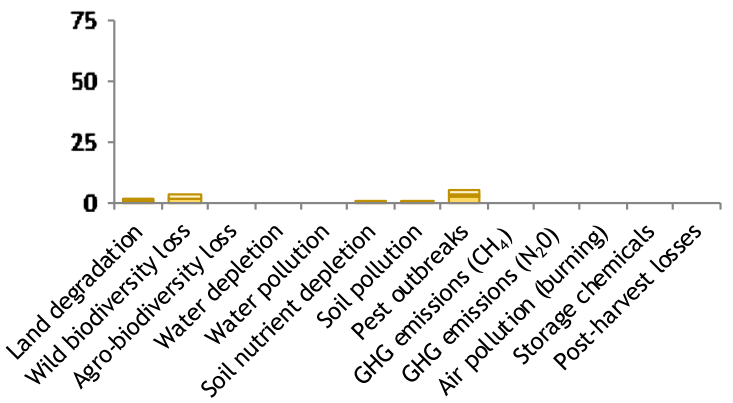

New publication (2013-2014)

Fig. 5 a-f Relative severity of environmental constraints and impacts, and the depth of environmental research for sweetpotato and yams in SubSaharan Africa (5a-c) and South Asia (5d-f)

(including Ringler et al. (2010) and Srivastava et al. (2012)) suggest sweetpotato and yam yields will decrease by $14 \%$ or more, depending on the soil type and climate change scenario.

\section{South Asia sweetpotato systems}

South Asia is not a significant producer of sweetpotato compared to Sub-Saharan Africa, and no yam production is officially reported (FAOSTAT 2013). Due to the relative lack of land to expand agriculture in South Asia, sweetpotato is a component of more intensive uses of existing cropland, particularly multi-crop sequences and rotations with major cereals and legumes. In contrast to the low-input sweetpotato/ yam systems typical of Sub-Saharan Africa, in South Asia both biological and chemical inputs are widely used in sweetpotato cultivation.

Key yield constraints for sweetpotato in South Asia include soil depletion/soil infertility, water unavailability and crop pests. Soil infertility is considered a severe constraint (Edison et al. 2009) though estimates of the yield gap are not available. Estimates of water constraints are similarly unavailable or outdated - in an early study in Tamil Nadu, for example, Goswami et al. (1995) found that irrigating three times during the growing season increased sweetpotato yields by $24 \%$ over non-irrigated sweetpotato crops. More recent field trials in Orissa, India have shown that intercropping sweetpotato with pigeonpea can increase soil quality, water retention and tuber yields under rainfed conditions (Nedunchezhiyan 2011). 
Regional pest control research is focused on weevil damage (Lebot 2009). Irrigation and the flooding of fields (which keeps the earth from cracking thus reducing weevil habitat) reduced weevil damage in some parts of Asia (Stathers et al. 2003).

Relative severity of environmental impacts Though sweetpotato production in South Asia is considered to have a low impact on the environment relative to cereal crops, some local environmental impacts may be appreciable owing to the relatively chemical-intensive production practices typical for many farmers in the region. The repeated cropping of sweetpotato as part of intensive multi-crop sequences and rotations in South Asia threatens to contribute to the degradation of soils and depletion of soil nutrients (Fig. 5e).

Research on environmental interactions and areas of debate We found limited research on environmental constraints or impacts of sweetpotato production in South Asia, with some attention on pest resistance (Fig. 5f). Almost no information is available for yam (which remains very uncommon in South Asia).

\section{Cassava crop x environment interactions}

Cassava (Manihot esculenta) is a widely-grown staple food root crop in the tropical and subtropical regions of Africa, Asia, and Latin America. Globally, the harvested area of cassava more than doubled between 1961 and 2012, from 9.6 $\mathrm{M}$ ha to $20.8 \mathrm{M}$ ha. Africa produced $149 \mathrm{M}$ t of cassava in $2012,56 \%$ of global production, followed by Asia with $33 \%$ (FAOSTAT 2013).

Probably due to its far greater importance and distribution in Sub-Saharan Africa, more research is available for environmental constraints and impacts of African cassava production systems compared to South Asian systems (see Fig. 6a-f). Nevertheless, considering its major importance in Africa there are relatively few publications available on cassava environmental interactions (Fig. 1b).

Traditional smallholder cassava systems (as found in much of Africa) have few environmental impacts in comparison to cereal crops - cassava does not require total clearing of forest for planting, it is easily intercropped, and (like other root crops) cassava can tolerate water stress better than many grain staples (Fermont et al. 2008; Fermont 2009). Cassava is also frequently grown with few inputs - minimizing environmental impacts from chemical contamination - although the crop tends to be grown on marginal nutrient-depleted soils and the disturbance of soil to harvest roots can lead to soil erosion. Biotic environmental constraints have major effects on cassava (see Fig. 6), particularly pests (mites, mealybugs, whiteflies (Bellotti 2002)) and associated viral diseases (cassava mosaic disease, cassava brown streak disease (Legg et al. 2006, 2011, 2014; FAO 2010)), as well as competition from weeds.

\section{Sub-Saharan Africa cassava systems}

Sub-Saharan Africa has experienced most of the worldwide increase in cassava production over the past 30 years, largely due to expanded area planted rather than yield gains (Fermont et al. 2008, 2009; Fermont 2009). The crop is widely grown in humid and sub-humid root crop-maize based farming systems across Sub-Saharan Africa (Waddington et al. 2010). The area of cassava harvested in Sub-Saharan Africa increased from 5.6 M ha in 1961 to $14.0 \mathrm{M}$ ha in 2012 (FAOSTAT 2013).

Many environmental impacts from cassava in Sub-Saharan Africa are land-use related (see Fig. 6a). Cassava often occupies hillsides, drought-prone areas and acidic soils where other crops cannot be grown or only with high inputs (Hershey and Howeler 2000). In West and East Africa, farmers frequently plant cassava on otherwise exhausted fields where little else will grow (e.g., Adjei-Nsiah et al. 2007; Fermont et al. 2008). Despite the crop's adaptability to poor soil conditions, depletion of soil fertility is an increasing challenge for cassava in many parts (Fermont et al. 2009). Crop losses due to poor soil fertility are severe (Waddington et al. 2010), with continuous farming of cassava harming soil fertility (Fermont et al. 2008). Little synthetic fertilizer is used for cassava, with fertilizers unavailable in remote areas, too costly, or reserved for other (mainly cereal) crops (Fermont 2009; Fermont et al. 2009; FAO 2001).

Biotic constraints and impacts are also important (Fig. 6a). Viral diseases (spread by the whitefly vector) are major concerns in Sub-Saharan Africa, especially cassava mosaic and cassava brown streak virus diseases which have devastated production in East and Central Africa (Legg et al. 2006, 2011, 2014; FAO 2010). Cassava bacterial blight (CBB) caused substantial yield losses throughout Sub-Saharan Africa in the 1970s, though much less research is available on the current impacts of the disease (Wydra and Verdier 2002; EPAR 2015). Pests, including mites and mealybugs, can reduce yields as much as $80 \%$ in Africa (Bellotti 2002), while uncontrolled weed growth can reduce yields by $95 \%$ (Melifonwu 1994), although handweeding (which is widely used) substantially reduces actual losses.

Additionally, cassava is highly susceptible to postharvest physiological deterioration (PPD). Harvested cassava roots deteriorate even more rapidly than those of other root/tuber crops such as yam or sweetpotato, which can lead to large volumes of the harvested crop being wasted (Karim and Fasasi 2009; Lebot 2009; Hodges et al. 2011; EPAR 2015). 
$\underline{\text { a Relative Severity of Cassava Constraints (SSA) }}$

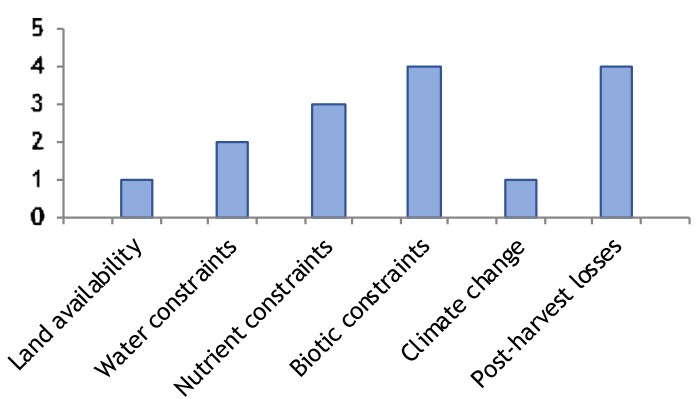

b Relative Severity of Cassava Impacts (SSA)
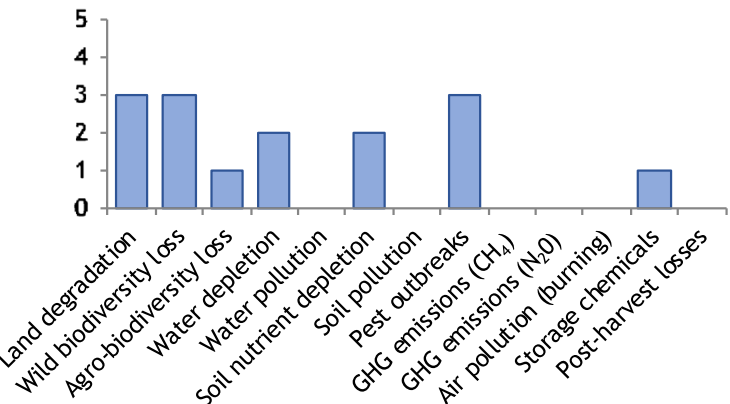

C Research on Cassava-Environment Interactions $\underline{(\mathrm{SSA})}$

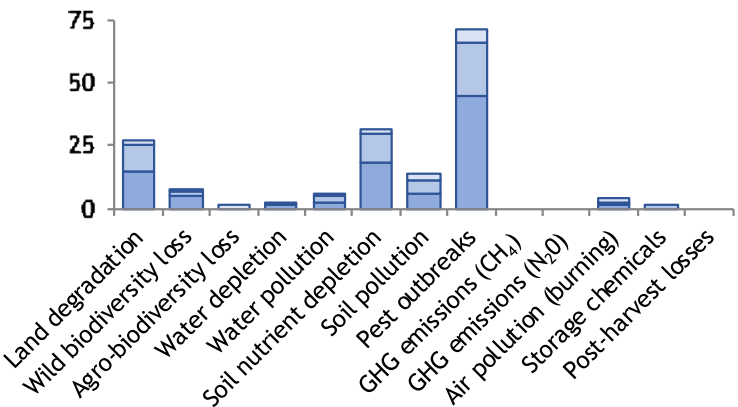

$>5$ citations since $2000 \quad 2-4$ citations since 2000 d Relative Severity of Cassava Constraints (SA)

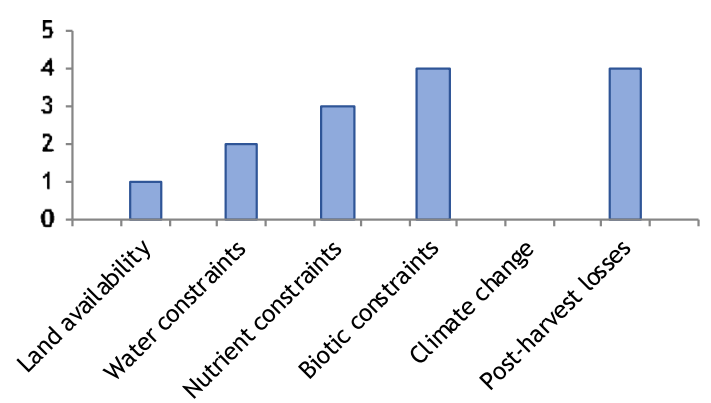

e Relative Severity of Cassava Impacts (SA)
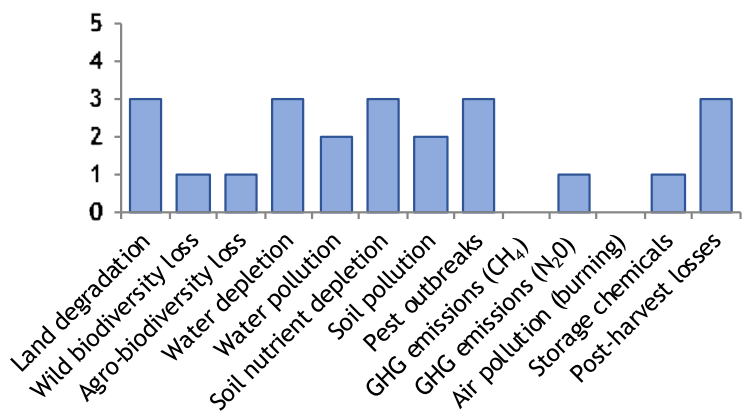

\section{$\underline{\text { f Research on Cassava-Environment Interactions }}$}

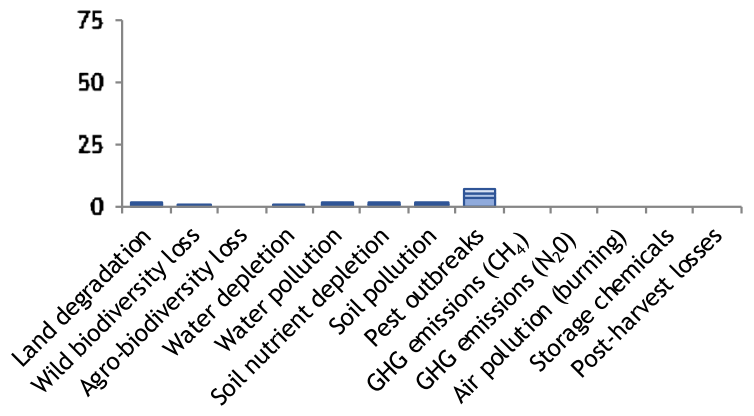

$\square$ New publication (2013-2014)

Fig. 6 a-f Relative severity of environmental constraints and impacts, and the depth of environmental research for cassava in Sub-Saharan Africa (6a-c) and South Asia (6d-f)

Relative severity of environmental impacts Cassava in Sub-Saharan Africa is often grown in or near forested agro-ecologies so expanding its area can continue to drive forest loss. Loss of biodiversity is also important (Fig. 6a, b), associated with the extremely large areas of cassava in the region and the important role of the crop in many of the areas undergoing deforestation for agricultural expansion. As little fertilizer is used on cassava in Africa, direct environmental impacts from fertilizer use are not substantial. Similarly, pesticides or herbicides have only local environmental impacts in Sub-Saharan Africa cassava systems because they are rarely used. However, hand weeding contributes to soil erosion (Melifonwu 1994) causing significant soil losses. Environmental damage associated with post-harvest processing and storage is also a concern, while substantial root losses add to the indirect environmental impacts of cassava through wasted effort in production.

\section{Research on environmental impacts and areas of} debate Once regarded as a relatively environmentally benign crop, the continued expansion of cassava into forested and marginal lands in Sub-Saharan Africa has increased the loss of forest, soil degradation and erosion. Considering its major importance in Africa, the research base on cassava interactions with the environment is (other than for pest resistance) generally extremely thin (Fig. 6c). This suggests that additional broad-based work studying environmental impacts with 
cassava systems in Sub-Saharan Africa (and their alleviation) could have high value.

\section{South Asia cassava systems}

Although widely grown overall in Asia, cassava is a crop of only secondary importance in South Asia. The area of cassava harvested in South Asia increased from $0.31 \mathrm{M}$ ha in 1961 to $0.55 \mathrm{M}$ ha in 1975 , but had fallen to $0.25 \mathrm{M}$ ha by 2012 , in part due to yield gains through intensification and to emerging preferences for other food crops. India is the principle cassava producer in South Asia, producing 8.7 M t in 2012 (FAOSTAT 2013). The crop is mainly grown in the southern states of Kerala and Tamil Nadu, with some production in Andhra Pradesh and the northeast (Onwueme 2002; Patil and Fauquet 2009).

The 2012 average yield for cassava in India was $36.1 \mathrm{t} / \mathrm{ha}$, compared to only $10.7 \mathrm{t} / \mathrm{ha}$ for Sub-Saharan Africa (FAOSTAT 2013). Higher yields in India are attributed to fewer pests and disease and more-intensive crop management, including irrigation and use of fertilizer, especially in Tamil Nadu (FAO 2001). Production practices vary by sub-region, with about $70 \%$ of India's cassava grown as a monoculture, and $30 \%$ intercropped with groundnut, vegetables and coconut (Hershey and Howeler 2000; Onwueme 2002). Supplemental irrigation is practiced only in the commercial cassava fields of Tamil Nadu (Howeler 2000).

\section{Relative severity of environmental impacts Environmental} impacts of cassava production in South Asia are mainly soil and water depletion and pollution attributable to the relatively intensive agricultural production practices employed (Fig. 6e). In the most intensive commercial cassava systems in south India, soil preparation with heavy machinery increases soil density and creates hard pans, degrading soils (FAO 2001; El-Sharkawy 2006), while synthetic fertilizer and pesticide application, along with irrigation, can contaminate soils and water sources or deplete supplies of surface and groundwater.

\section{Research on environmental impacts and areas of} debate Hardly any research has been published recently on the environmental impacts of cassava in South Asia (Fig. 6f). Unlike in Sub-Saharan Africa, issues with agricultural expansion seem irrelevant in the region as the cassava area is contracting. Agricultural intensification, however, can have negative environmental impacts - although such potential impacts remain under-studied in South Asia cassava systems. Like Sub-Saharan Africa, cassava in South Asia depletes soil nutrients, but it is possible the widespread use of fertilizers in Indian cassava production may have a net positive impact on nutrient management. Nevertheless, as fertilizer use has continued to grow in South Asian cassava farming systems (both directly for cassava and indirectly through application for intercrops) there is potential for exacerbating other environmental problems such as the pollution of soil and water.

\section{Discussion}

\section{Severity of environmental constraints across regions and crops}

While it is clear that many different types of production constraint affect all food crops in Sub-Saharan Africa and South Asia, our study suggests large differences in the relative importance of different categories of constraint by crop and by region.

Land constraints are considered among the most severe barriers to rice production in South Asia, but barely feature in the published literature on Sub-Saharan Africa. Limited or unpredictable water supplies are assessed as severe for rice in both regions, but are especially acute in Sub-Saharan Africa. Limited and depleting nutrients are also felt severely in both regions (Fig. 2). For maize, many diverse constraints are considered important, especially in Sub-Saharan Africa (Fig. 3). Among these, those related to soil fertility and nutrients are especially severe, as are land availability and biotic constraints in South Asia. Water constraints, biotic constraints and climate change are all also rated important for maize in Sub-Saharan Africa. With sorghum/millets, water shortages are considered extremely severe in Sub-Saharan Africa, but far less so in South Asia (Fig. 4). Biotic constraints are felt to be severe in both Sub-Saharan Africa and South Asia, as are nutrient constraints. Limited land availability is also an issue for sorghum/ millets, but for the most part only in South Asia. For sweetpotato/yam in both Sub-Saharan Africa and South Asia biotic constraints are considered to be the most severe, while water constraints also feature highly, especially in South Asia (Fig. 5). Post-harvest losses and nutrient constraints, meanwhile, are more important in Sub-Saharan Africa. Finally, with cassava, the pattern of importance among constraint categories is viewed very similarly for both Sub-Saharan Africa and South Asia (Fig. 6). Those related to biotic constraints and post-harvest losses are cited as the most severe, followed by nutrients and then water constraints. Indeed, in general, biotic constraints such as diseases and pests are frequently considered more severe for root crops than the cereals, which are affected more by various abiotic constraints, particularly access to water and soil nutrients (Figs. 2, 3, 4, 5 and 6).

\section{Severity of crop $x$ environment impacts and depth of recent research}

Drawing on the results of our search of the Scopus database for papers published since 2000 (and acknowledging several methodological limitations that we discuss below), we find 
that evidence on environmental impacts in smallholder crop production systems is also highly uneven across crops and across the Sub-Saharan Africa and South Asian regions and ecologies. While some environmental impacts of smallholder agricultural systems are consistently reported in the literature (indicating a relatively strong understanding and/or consensus on these impacts) others are not (suggesting the need for more research, especially for severe impacts). In other cases, scientific consensus for a given environmental impact is high but much of the literature with a crop or farming system is more than 10 years old, possibly reflecting earlier but now declining interest in the issue. One example is the significant amount of older work that was published on soil losses from agricultural systems. In this case although commonly recognized as still a key concern, the importance of soil losses may not be fully reflected in recent publications.

Despite the variations, there were some notable patterns in the treatment of crop $\mathrm{x}$ environment interactions in the published literature revealed by our 2000 to 2014 Scopus literature search (Figs. 2, 3, 4, 5 and 6 and summarized in Fig. 7). The relative attention to different crops and different environmental factors in Sub-Saharan Africa is in clear contrast to South Asia (Fig. 1b). For Sub-Saharan Africa, several categories of environmental impact across the crops are well represented in the literature, especially those covering land degradation, soil nutrient depletion and pest resistance. There has been a particular emphasis on the land degradation and soil nutrient depletion impacts of maize and to some extent for sorghum/millets, and major attention given to pest resistance and post-harvest loss issues with sweetpotato/yam. Other impacts, especially agro-biodiversity loss, water depletion, air pollution, GHG emissions, and storage chemicals barely featured in the literature for Sub-Saharan Africa. Most of the crop $\mathrm{x}$ environment literature we found for South Asia is for rice, followed by maize and sorghum/millets (mostly pearl millet).
As with Sub-Saharan Africa, in South Asia there is substantial representation of work on soil degradation, pest resistance and soil nutrient depletion in the literature. Additionally there is an emphasis (much greater than with Africa) on water pollution, soil pollution, and to a lesser extent air pollution, with all three issues dominated by research for rice and rice-wheat systems. Few publications were found for biodiversity and storage chemicals, while numbers of publications on water depletion and GHG emissions are intermediate but again almost exclusively reported for rice.

There have been also interesting changes in the amount of reported work on the impact categories over the period 2000 2014 (Fig. 8a-b). The emphasis on publications that address land degradation and soil nutrient depletion for maize systems in Sub-Saharan Africa was especially strong in the 2000s but has declined in recent years (Fig. 8b). Several publications on water and soil pollution with maize have appeared since 2010, unlike the early 2000s when there were very few. In South Asia, the frequency of publications on soil and water pollution and on land degradation for rice is also increasing. Only in recent years have a few papers been published on biodiversity loss in rice systems in South Asia. There has also been a trend to more publications on soil nutrient depletion with maize in South Asia in recent years, while almost all those on water depletion, water pollution and soil pollution for maize started to appear only after 2005 .

In contrast to increased published research with all the other crops, there has been a decline in the number of sorghum/ millet publications for several environmental issues in recent years, including those on soil nutrient depletion, pest resistance and post-harvest issues. However, interest in wild biodiversity loss has risen somewhat, as is also noted for the other cereals. With sweetpotato/yam in Sub-Saharan Africa, some of the issues that received considerable attention in the early 2000s appear to have further increased in popularity since

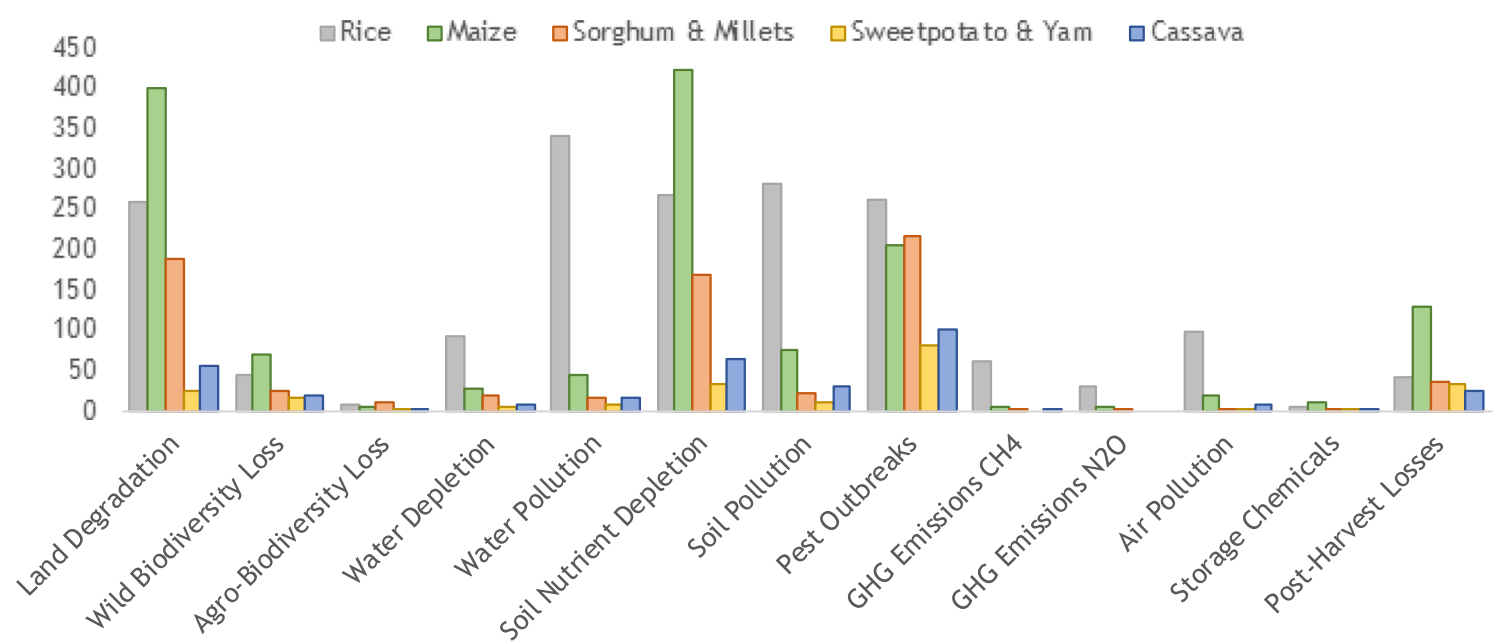

Fig. 7 The number of publications on 13 categories of environmental impact for important food crops in Sub-Saharan Africa and South Asia, 20002014 

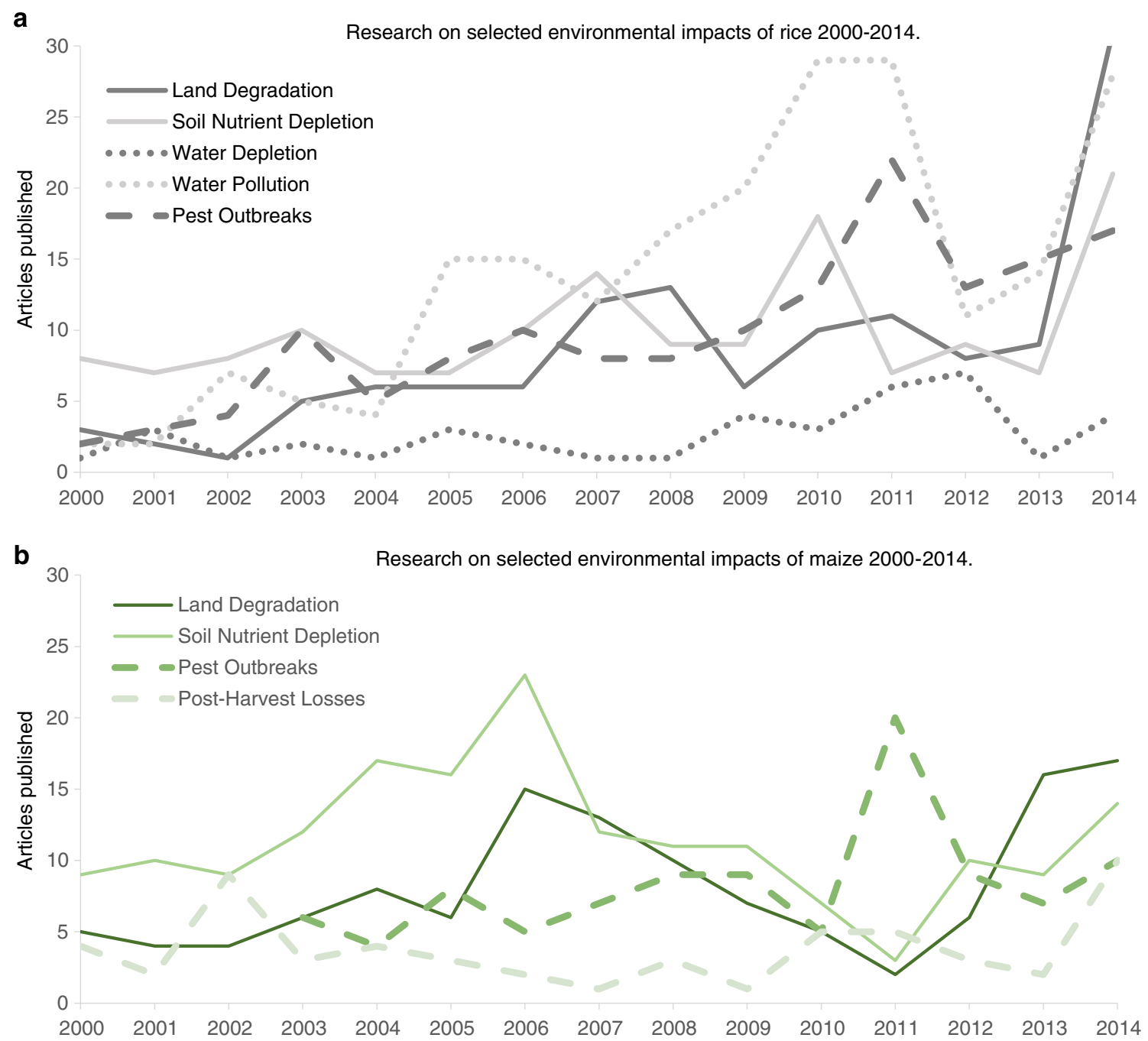

Fig. 8 Trends with numbers of publications for environmental impacts of rice (8a) and maize (8b) over the period 2000-2014 in Sub-Saharan Africa and South Asia

then, including pest resistance, post-harvest losses, and land degradation. Finally, cassava is a crop of some importance in parts of south India, but apart from a little work on pest resistance there is almost no published research on other environmental impacts of cassava production, including potential impacts with direct repercussions for future cassava production, especially soil nutrient depletion and water depletion.

Some noteworthy gaps in crop- and region-specific research emerge from this summary assessment of the recent literature. For example, given the rising concern about water depletion and scarcity in agriculture in Sub-Saharan Africa, the underrepresentation of work in this area is surprising (much of the research on water scarcity would be crop-related and thus should feature in our Scopus counts) and merits increased consideration. The paucity of maize research in South Asia is another noteworthy gap, although as maize becomes more important in South Asian cropping systems it is likely to feature more in environmental impact work that currently appears to have been almost exclusively for rice. There also remain literature gaps in research on water depletion for sorghum $/ \mathrm{mil}$ lets, and on ways to address biodiversity issues for the varied intensive cereal systems in South Asia. On- and off-farm biodiversity loss for crops such as maize, sorghum/millets and cassava, and GHG emissions and air pollution more generally, could all benefit from more attention, particularly in SubSaharan Africa. And given that cassava is such an important and widely grown food crop in Africa, there is surprisingly little published literature available for most potential environmental impacts, suggesting another research area of high value.

\section{Limitations to the assessments}

There are several scale- and method-related limitations to these crop-based assessments of environmental impacts and constraints.

Firstly, smallholder farmers grow these crops in diverse and sometimes complex farming systems, rather than independently. Thus the degree of interaction of crops with the 
environment varies widely across the many farming systems within Sub-Saharan Africa and South Asia. The food crops we included in this assessment are very important in at least four major farming systems in Sub-Saharan Africa (according to the farming systems classification described in Dixon et al. (2001)). These include the Root Crop system (yams, cassava and sweetpotato, with sorghum, maize and rice in some areas), the Cereal-Root Crop Mixed system (sorghum, millets, cassava, yams, sweetpotato, maize and rice), the Maize Mixed system (largely maize, with some cassava, millets, sorghum and sweetpotato), and the Agro-Pastoral (Millet/Sorghum) system (sorghum and pearl millet, with some maize). In addition, root crops and maize are also found in other Sub-Saharan Africa systems such as the Humid Lowland Tree Crop system, the Forest Based system and the Highland Perennial system. Rice is increasingly important in the Irrigated system. Five farming systems incorporate the crops in South Asia; the Highland Mixed system (where rice and maize are very important), the Rice system (two-season rice (rainfed and irrigated) is important, with some maize, and some cassava in the south), the Rice-Wheat system (rainfed and irrigated rice and maize are important, with some sorghum), the Rainfed Mixed system (rice, rainfed maize, sorghum and millets), and the Dry Rainfed system (sorghum and millets are important, with some other irrigated cereals).

Because combinations of crops are important in many farming systems, for these multi-crop systems the environmental constraints and impacts are a summation of contributions from several single crops, and there may sometimes be complex interactions among the multiple crops in the systems and the environment. Additionally, other food crops such as wheat and grain legumes, and livestock - not included in the current paper - are widely found in some systems and these also have important environmental impacts. The different crops can have contrasting roles in the farming system and different types and levels of environmental interaction. In the Maize Mixed and Cereal-Root Crop Mixed systems in Sub-Saharan Africa for example, maize may often be found as an initial crop associated with land clearing and slash-andburn agriculture, while cassava may be a last resort-crop on exhausted fields in those systems before the fields are returned to bush fallow. Necessarily, intensive cultivation of rice in the Rice and Rice-Wheat systems of South Asia will have far greater impacts on soil nutrient depletion, and water and pesticide contamination than does sparse low input and output sorghum and millet production in the Agropastoral system of Sub-Saharan Africa. Also, the types of environmental impacts may differ widely for the same crops in different systems. For example, while rice and maize are often associated with soil erosion on hill slopes in the Highland Mixed system of South Asia, those same crops may be linked more with the buildup of pests and weeds on the intensively cultivated flatland in the South Asia Rice system.
Additionally, there are limitations to the publication analysis methods used in the present study. By restricting the quantitative analysis to peer-reviewed papers published since 2000 we are omitting a great deal of older published work and nonpeer-reviewed reports on crop-environmental interactions. By relying on the Scopus citation database we are also missing many non-English journals as well as various national and regional journals that are making significant contributions. Finally, a large body of important research on relevant largescale environmental issues has been conducted without reference to specific crops and farming systems. The loss of biodiversity associated with agricultural activity, for example, is often demonstrated for an agroecology or ecosystem rather than for a crop grown on farm fields, while climate change effects can be found globally, frequently well away from the origin of their causes. Soil-related environmental interactions such as erosion are often assessed for a watershed, soil catena or soil type (rather than for a specific crop), and the environmental impacts of pesticides, air pollution and storage chemicals are often associated with biodiversity or human health studies which may not reference specific crops. To the extent that only general studies (rather than crop-specific or region-specific studies) existed on a given environmental problem relevant information was selected where possible; but it remains true that some of this broader work will not have been captured in the literature surveys we reported here.

\section{Good practices to manage crop $x$ environment interactions}

Since the environmental constraints and impacts of greatest significance vary by crop and by farming system, the "good" practices to manage them are numerous and often contextspecific (Waddington et al. 2010). Appropriate strategies to overcome constraints and minimize environmental impacts vary widely based on factors such as local environmental conditions, household resources, cultural preferences, production practices, market access, and public policies, and lessons learned in one region may only be loosely applicable to the same crops being grown in a different region with a different ecological and social context (Pingali 2012). Moreover "good" practices in a given place may change over time with changing crop systems and a changing climate (Lobell et al. 2011b).

Nevertheless, in virtually all smallholder crop systems, yield gains can be realized - and many environmental damages reduced or averted - through the relatively wellunderstood interventions of:

- Improved water management, including proper soil preparation, crop selection and timing of planting to reduce runoff and utilize available water resources even in the absence of irrigation (Pretty et al. 2006, 2011; Pfwaster 
et al. 2011; Chartres and Noble 2015). Efforts to overcome water constraints on crop production in smallholder systems include irrigation and other water management practices, and the use of diverse and drought resistant varieties, depending on local contexts (de Fraiture et al. 2010; Li et al. 2011);

- Improved soil management, including ensuring farmers do not over-use fertilizers, and promoting the use of crop rotations, intercropping with leguminous species, reduced tillage and incorporating agricultural residues (Snapp et al. 1998; Singh et al. 2009; Vanlauwe et al. 2010; Fageria 2011; Chartres and Noble 2015). Minimal tillage and the retention of crop residues in particular can often reduce soil erosion, reduce GHGs and support soil fertility, and may raise yields (e.g., Tuong et al. 2005; Hobbs et al. 2008). For many SubSaharan Africa smallholder cropping systems, implementing rotations and intercrops, along with organic manures and targeted small amounts of synthetic fertilizer all frequently raise crop yields and financial returns from investments in inputs, while also improving food system stability (reducing risks of total crop failure) and the diversity of foods produced (e.g., Snapp et al. 1998, 2010; Twomlow et al. 2010; Pretty et al. 2011; Thierfelder et al. 2012);

- Improved pest (including disease and weed) management through integrated pest management (IPM), including judicious pesticide use (Oerke and Dehne 2004; Williamson et al. 2008) but relying primarily on interventions supporting crop health and discouraging pest outbreaks (such as through intercropping and use of 'push-pull' systems to attract and trap pests (Khan et al. 2011)), have seen growing effectiveness and acceptance among farmers.

Improved pre-production decisions, including sparing marginal lands and ecologically important areas from cropping, as well as efforts to reduce post-harvest losses through improved storage methods and facilities (World Bank 2011; Tefera 2012) are additional general considerations to mitigate environmental impacts that apply across the crops and regions. Indeed, a growing body of empirical evidence from SubSaharan Africa suggests more concerted efforts to match the "right use to the right land" could result in increased food production and increased wild habitat conservation simultaneously (Rodenburg et al. 2014). Concentrating farmers' cropping efforts on relatively more productive croplands can directly increase harvests (e.g., Giller et al. 2006), while sparing ecologically sensitive (and often low-productivity) sloped and hilltop land from cropping can further increase the amount and stability of crop yields through improved water retention, erosion control, and provision of ecosystem services (Rodenburg et al. 2014).
Advances in crop breeding also help to alleviate some environmental constraints and possibly reduce negative environmental impacts of crop production - although to date the effectiveness of modern varieties for advancing smallholder productivity has been mixed and there is little evidence that they reduce environmental impacts of cropping. Much of the breeding in sorghum and millets, for example, has focused on increasing yields under ideal conditions, rather than in variable climatic conditions or on marginal land (Schlenker and Lobell 2010). And many of the advances with hybrid maize crops have focused on sole crop high-input systems typical of industrialized 'Western' agriculture rather than complex lower-input systems used by most farmers in Sub-Saharan Africa and many in South Asia. For these conditions there often remain more-traditional cereal varieties that, though lower-yielding under ideal conditions, generally perform well and may out-perform many modern varieties in times of drought or input scarcity, making these varieties attractive to risk-averse smallholders in low impact systems.

Climate change may offer new cost-effective opportunities for African smallholder farmers to combine the appropriate choice of crops and improved varieties with suited management options such as modified planting dates and fertilizer use to mitigate climatic effects (e.g., Waha et al. 2013; Rurinda et al. 2014). Future climate change will likely be especially damaging to maize yields in SubSaharan Africa, exacerbating the severity of several biotic and abiotic constraints, including high temperatures, drought and pests, and reducing the areas where maize can be grown. Some progress has been made to breed and use maize with better tolerance to drought and high temperatures (see Bänziger et al. 2006; Shiferaw et al. 2011; Cairns et al. 2013), but larger improvements are needed as maize production is likely to be substantially constrained by these abiotic stresses in Sub-Saharan Africa and South Asia.

For rice in South Asia, several improved land and crop management practices can raise yields while reducing environmental impacts, including more efficient irrigation, direct seeding, improved fertilization and effective weed control (e.g., Tuong et al. 2005; Pampolino et al. 2007). Several reduced tillage management options to help conserve soils in South Asia rice-wheat cropping systems have been developed and are increasingly used (Gupta and Sayre 2007; Erenstein et al. 2012), while the rising costs of irrigation are already driving shifts from irrigated rice towards other more waterefficient food crops such as maize (Pfwaster et al. 2011).

With maize, there is now a substantial body of research on the sustainable intensification of maize-based cropping systems in Sub-Saharan Africa, and increasingly so in South Asia. Many good practices and technologies are available to manage the environmental impacts of maize systems (see Pretty et al. 2011), and frequently similar prescriptions also 
apply to sorghum/millets production. These include improved soil and water conservation methods (e.g., Fowler and Rockström 2001; Hobbs et al. 2008; Erenstein et al. 2012), integrated nutrient management (e.g., Vanlauwe et al. 2010; Timsina et al. 2010, 2011), the retention and use of biodiversity on crop fields (Mapfumo et al. 2005; Snapp et al. 2010) and the improved management of farm fields with different nutrient status (e.g., Giller et al. 2006; Tittonell et al. 2008). Across Sub-Saharan Africa, many of the more-traditional maize systems maintain productivity while reducing abiotic and biotic environmental impacts by intercropping or rotating leguminous trees and shrubs, and annual legumes with maize (Snapp et al. 1998, 2010; Waddington et al. 2007; Ajayi et al. 2011; Pretty et al. 2011), or by incorporating legume weed residues into croplands (Mapfumo et al. 2005). The expansion of such practices should be encouraged. Improved small-scale on-farm post-harvest processing and storage technologies include better grain drying procedures and the use of small metal silos and hermetically-sealed air-tight plastic grain bags and drums that are very effective for cereals including rice, maize, wheat and others (e.g., Tefera 2012).

As for the lesser-studied root and tuber crops, good practices for sustainable and low environmental impact sweetpotato and yam production include manure application and mulching to increase soil nutrients and moisture (Bridge et al. 2005), as well as crop rotation, intercropping and site cleaning (burning infected plant material) to reduce pest and disease risks (Stathers et al. 2003). The use of disease-free growing material and judicious use of chemicals (e.g., dipping vines in insecticide prior to planting to delay infestations) is also recommended to mitigate potentially heavy losses from disease (Lebot 2009). Also, while climate change has the potential to lower the yields of many crops across Sub-Saharan Africa and South Asia (Srivastava et al. 2012), some research suggests sweetpotato and yam may be relatively resilient to changing climate, and could help fill gaps left by declining production in other crops.

Good practices to manage environmental impacts of cassava include the expanded use of intercropping (including with trees and bushes) and the incorporation of crop residues into soils after harvest to maintain soil fertility (Howeler 2002). The use of clean planting material is key to managing viral diseases with cassava, but delivering that requires coordinated work in several areas such as surveillance, integrated whitefly pest management, crop breeding and seed systems (Legg et al. 2006, 2014). Better storage of roots in the soil, improved harvest and storage practices and improved processing methods are especially useful to reduce post-harvest losses with cassava (Lebot 2009). For the future, largely because of its tolerance to drought and high temperatures, cassava is expected to be more resilient to climate change than maize, rice, sorghum, and some of the millets and may be increasingly used as a replacement for cereals (Paavola 2008; Jarvis et al. 2012).

\section{Conclusions}

All agriculture inevitably changes the natural environment. However in many instances, harm to natural ecological systems is either unnecessary (as all or part of the ecosystem could be maintained without significant losses in food output) or outright undesirable (because a wholly or partially intact ecosystem could provide more benefits in terms of local or regional food production than cultivating an extra parcel of marginal cropland). This review of five important food crops in Sub-Saharan Africa and South Asia has emphasized that there are feedback loops inherent in all agro-ecological systems - the environmental constraints that limit crop productivity cannot be fully understood independently of the crop management practices that comprise and impact the environment. Our assessment indicates that the production of these food crops has diverse and sometimes large impacts on the environment which vary by crop and region. To sustain productive agriculture, these impacts need to be managed and reduced. Much is now known about a widening array of good management practices to mitigate environmental impacts. This value-chain and crop $\mathrm{x}$ environment interaction framework and the findings on environmental impacts and good practices should help support further across-system and across-crop discussions on the wide range of crop $\mathrm{x}$ environment interactions encountered in agricultural development initiatives.

Acknowledgments This paper is based on a set of briefs in the "Agriculture-Environment Series: Current Knowledge of Crop x Environment Interactions in Sub-Saharan Africa and South Asia" produced for the Agricultural Development Group at the Bill and Melinda Gates Foundation. We thank the Bill \& Melinda Gates Foundation for their support. The findings and conclusions presented here are those of the authors and do not necessarily reflect positions or policies of the foundation.

Open Access This article is distributed under the terms of the Creative Commons Attribution 4.0 International License (http://creativecommons.org/licenses/by/4.0/), which permits unrestricted use, distribution, and reproduction in any medium, provided you give appropriate credit to the original author(s) and the source, provide a link to the Creative Commons license, and indicate if changes were made.

\section{References}

Adjei-Nsiah, S., Kuyper, T. W., Leeuwis, C., Abekoe, M. K., \& Giller, K. E. (2007). Evaluating sustainable and profitable cropping sequences with cassava and four legume crops: effects on soil fertility and maize yields in the forest/savannah transitional agroecological zone of Ghana. Field Crops Research, 103, 87-97.

Africa Rice Center. (2010). Africa Rice Center (AfricaRice) Annual report 2009: Increasing investment in Africa's rice sector. Cotonou. 
Agbaje, G. O., Ogunsumi, L. O., Oluokun, J. A., \& Akinlosotu, T. A. (2005). Survey of yam production system and the impact of government policies in southwestern Nigeria. Journal of Food, Agriculture and Environment, 3(2), 222-229.

Ahmed, M. M., Sanders, J. H., \& Nell, W. T. (2000). New sorghum and millet cultivar introduction in Sub-Saharan Africa: impacts and research agenda. Agricultural Systems, 64, 55-65.

Ajayi, O. C., Place, F., Akinnifesi, F. K., \& Sileshi, G. W. (2011). Agricultural success from Africa: the case of fertilizer tree systems in southern Africa (Malawi, Tanzania, Mozambique, Zambia and Zimbabwe). International Journal of Agricultural Sustainability, 9(1), 129-136.

Ali, M. Y., Waddington, S. R., Timsina, J., Hodson, D., \& Dixon, J. (2009). Maize-rice cropping systems in Bangladesh: status and research needs. Journal of Agricultural Science and Technology USA, $3(6), 35-53$.

Altieri, M. A., \& Nicholls, C. I. (2004). Biodiversity and pest management in agroecosystems (2nd ed.). Binghamton: Food Products Press.

Amusa, N. A., Adegbite, A., Muhammed, S., \& Baiyewu, R. A. (2003). Yam diseases and its management in Nigeria. African Journal of Biotechnology, 2(12), 297-502.

Andrade, M., Barker, I., Cole, D., Dapaah, H., Elliott, H., Fuentes, S., Grüneberg, W., Kapinga, R., Kroschel, J., Labarta, R., Lemaga, B., Loechl, C., Low, J., Lynam, J., Mwanga, R., Ortiz, O., Oswald, A., $\&$ Thiele, G. (2009). Lima: Unleashing the potential of Sweetpotato in Sub-Saharan Africa: Current challenges and way forward. International Potato Center (CIP). Working Paper 2009-1.

Andreae, M. O., \& Merlet, P. (2001). Emission of trace gases and aerosols from biomass burning. Global Biogeochemical Cycles, 15(4), 955-966.

ASARECA (2005). Potato and Sweetpotato. Association for Strengthening Agricultural Research in Eastern and Central Africa (ASARECA)

Bagamba, F., Bashaasha, B., Claessens, I., \& Antle, J. (2012). Assessing climate change impacts and adaptation strategies for smallholder agricultural systems in Uganda. African Crop Science Journal, 20(2), 303-316.

Bai, Z. G., Dent, D. L., Olsson, L., \& Schaepman, M. E. (2008). Proxy global assessment of land degradation. Soil Use and Management, 24(3), 223-234.

Bänziger, M., Setimela, P. S., Hodson, D., \& Vivek, B. (2006). Breeding for improved abiotic stress tolerance in maize adapted to southern Africa. Agricultural Water Management, 80(1-3), 212-224.

Barker, R., Meinzen-Dick, R., Shah, T., Tuong, T.P., \& Levine, G. (2010). Managing irrigation in an environment of water scarcity. In Rice in the global economy: Strategic research and policy issues for food security (p. 333). Manila: 2.6: International Rice Research Institute (IRRI).

Basavaraj, G., Parthasarathy Rao, P., Bhagavatula, S., \& Ahmed, W. (2010). Availability and utilization of pearl millet in India. SAT eJournal, 8.

Beed, F. D. (2014). Managing the biological environment to promote and sustain crop productivity and quality. Food Security, 6(2), 169-186.

Bellotti, A. C. (2002). Arthropod pests. In R. J. Hillocks \& A. Bellotti (Eds.), Cassava: Biology, production and utilization (pp. 209-235). Wallingford: CABI Publishing.

Binam, J. N., Tonye, J., Nyambi, G., \& Akoa, M. (2004). Factors affecting the technical efficiency among smallholder farmers in the slash and burn agriculture zone of Cameroon. Food Policy, 29(5), 531-545.

Bommarco, R., Kleijn, D., \& Potts, S. G. (2013). Ecological intensification: harnessing ecosystem services for food security. Trends in Ecology \& Evolution, 28(4), 230-238.

Bossio, D., Geheb, K., \& Critchley, W. (2010). Managing water by managing land: addressing land degradation to improve water productivity and rural livelihoods. Agricultural Water Management, 97(4), 536-542.

Bouman, B. A. M., Humphreys, E., Tuong, T. P., \& Barker, R. (2007). Rice and water. Advances in Agronomy, 92, 187-237.

Bridge, J., Coyne, D., \& Kwoseh, C. K. (2005). Nematode parasites of tropical root and tuber crops. In M. Luc, R. Sikora, M. Luc, R.
Sikora, \& J. Bridge (Eds.), Plant parasitic nematodes in subtropical and tropical agriculture (Revised 2nd ed., pp. 221-258). Wallingford: CAB International.

Burke, M. B., Lobell, D. B., \& Guarino, L. (2009). Shifts in African crop climates by 2050 , and the implications for crop improvement and genetic resources conservation. Global Environmental Change, 19, $317-325$.

Cairns, J. E., Hellin, J., Sonder, K., Araus, J. L., MacRobert, J. F., Thierfelder, C., \& Prasanna, B. M. (2013). Adapting maize production to climate change in sub-Saharan Africa. Food Security, 5(3), 345-360.

Cassman, K. G., Dobermann, A., Walters, D. T., \& Yang, H. (2003). Meeting cereal demand while protecting natural resources and improving environmental quality. Annual Review of Environment and Resources, 28(1), 315-358.

Chartres, C. J., \& Noble, A. (2015). Sustainable intensification: overcoming land and water constraints on food production. Food Security, $7(2), 235-245$

CIP. (2010). Facts and figures about sweetpotato. Lima: International Potato Center.

Claessens, L., Antle, J., Stoorvogel, J.J., Thornton, P.K., \& Herrero, M. (2010). Assessing Climate Change Adaptation Strategies for Small Scale, Semi-subsistence Farming. Retrieved from: http://www. researchgate.net/publication/

Clay, J. (2004). World agriculture and the environment. Washington: Island Press.

Cobo, J. G., Dercon, G., \& Cadisch, G. (2010). Nutrient balances in African land use systems across different spatial scales: a review of approaches, challenges and progress. Agriculture, Ecosystems \& Environment, 136(1), 1-15.

Cooper, P. J. M., Dimes, J., Rao, K. P. C., Shapiro, B., Shiferaw, B., \& Twomlow, S. (2008). Coping better with current climatic variability in the rain-fed farming systems of sub-Saharan Africa: an essential first step in adapting to future climate change? Agriculture, Ecosystems \& Environment, 126(1-2), 24-35.

Dawe, D., Pandey, S., \& Nelson, A. (2010). Emerging trends and spatial patterns of rice production. In S. Pandey, D. Byerlee, D. Dawe, A. Dobermann, M. Samarendu, S. Rozelle, \& B. Hardy (Eds.), Rice in the global economy: Strategic research and policy issues for food security (p. 333). Manila: 2.6: International Rice Research Institute (IRRI).

de Fraiture, C., Molden, D., \& Wichelnsa, D. (2010). Investing in water for food, ecosystems, and livelihoods: an overview of the comprehensive assessment of water management in agriculture. Agricultural Water Management, 97, 495-501.

Dixon, J., Gulliver, A., \& Gibbon, D. (2001). Farming systems and poverty: Improving farmers' livelihoods in a changing world. Rome: FAO and World Bank.

Dobermann, A. (2004). A critical assessment of the system of rice intensification (SRI). Agricultural Systems, 79(3), 261-281.

Dobermann, A., \& Fairhurst, T. (2000). Rice: Nutrient disorders \& nutrient management. IRRI, the Philippines, PPI, USA, and PPIC, Canada.

Dogliotti, S., Giller, K. E., \& Van Ittersum, M. K. (2014). Achieving global food security whilst reconciling demands on the environment: report of the First International Conference on Global Food Security. Food Security, 6(2), 299-302.

Edison, S., Hegde, V., Makeshkumar, T., Srinivas, T., Suja, G., \& Padmaja, G. (2009). Sweetpotato in the Indian Sub-Continent. In G. Loebenstein \& G. Thottappilly (Eds.), The sweetpotato (pp. 391414). Dordrecht: Springer.

El-Sharkawy, M. A. (2006). International research on cassava photosynthesis, productivity, eco-physiology, and responses to environmental stresses in the tropics. Photosynthetica, 44(4), 481-512.

Erenstein, O., Sayre, K., Wall, P., Hellin, J., \& Dixon, J. (2012). Conservation agriculture in maize- and wheat-based systems in the (sub)tropics: Lessons from adaptation initiatives in South Asia, 
Mexico, and Southern Africa. Journal of Sustainable Agriculture, 32(2), 180-206.

Evans Policy Analysis and Research Group (EPAR). (2015). Cassava bacterial blight and postharvest physiological deterioration. EPAR Brief No. 298. Retrieved from: https://evans.uw.edu/ centers-projects/epar/epar-research

Ewell, P. (2011). Sweetpotato production in Sub-Saharan Africa: Patterns and key issues. Kenya: Nairobi.

Fageria, N. K. (2011). Growth and mineral nutrition of field crops. Boca Raton: CRC Press.

FAO (2001). Proceedings of the Validation Forum on the Global Cassava Development Strategy '00: Strategic environmental assessment, an assessment of the impact of cassava production and processing on the environment and biodiversity. Rome: Food and Agricultural Organization of the United Nations (FAO). Retrieved from http:// www.fao.org/docrep/007/y2413e/y2413e00.htm

FAO (2010). Cassava diseases in Africa: a major threat to food security. Rome: Food and Agricultural Organization of the United Nations (FAO). Retrieved from http://www.fao.org/fileadmin/templates/fcc/ documents/CaCESA_EN.pdf

FAO $(2013,2012,2010)$. FAOSTAT. Food and Agricultural Organization of the United Nations (FAO), Rome. Retrieved from http://faostat.fao.org

Fargione, J., Hill, J., Tilman, D., Polasky, S., \& Hawthorne, P. (2008). Land clearing and the biofuel carbon debt. Science, 319(5867), $1235-1238$

Fermont, A.M. (2009). Cassava and soil fertility in intensifying smallholder farming systems of East Africa. PhD thesis, Wageningen University, The Netherlands.

Fermont, A. M., Van Asten, P. J. A., \& Giller, K. E. (2008). Increasing land pressure in East Africa: the changing role of cassava and consequences for sustainability of farming systems. Agriculture, Ecosystems \& Environment, 128(4), 239-250.

Fermont, A. M., Van Asten, P. J. A., Tittonell, P., Van Wijk, M. T., \& Giller, K. E. (2009). Closing the cassava yield gap: an analysis from smallholder farms in East Africa. Field Crops Research, 112(1), 24-36.

Fowler, R., \& Rockström, J. (2001). Conservation tillage for sustainable agriculture: an agrarian revolution gathers momentum in Africa. Soil and Tillage Research, 61, 93-108.

Fuglie, K. O. (2007). Priorities for sweetpotato research in developing countries: results of a survey. HortScience, 42(5), 1200-1206.

García-Ponce, E., Gómez-Macpherson, H., Diallo, O., Djibril, M., Baba, C., Porcel, O., Mathieu, B., Comas, J., Mateos, L., \& Connor, D. J. (2013). Contribution of sorghum to productivity of small-holder irrigation schemes: on-farm research in the Senegal River Valley, Mauritania. Agricultural Systems, 115, 72-82.

Garí, J.A. (2002). Review of the African millet diversity. International workshop on fonio, food security and livelihood among the rural poor in West Africa. IPGRI/IFAD, Bamako, Mali, 19-22 November 2001.

Gerpacio, R., \& Pingali, P. (2007). Tropical and subtropical maize in Asia. Mexico: CIMMYT. Retrieved from http:// repository.cimmyt.org/xmlui/bitstream/handle/10883/800/ 90044.pdf? sequence $=1$

Gibbon, D., Dixon, J., \& Flores, D. (2007). Beyond drought tolerant maize: Study of additional priorities in maize. Report to CGIAR Generation Challenge Program. CIMMYT Impacts, Targeting and Assessment Unit, CIMMYT. México DF, México.

Giller, K. E., Rowe, E. C., de Ridder, N., \& van Keulen, H. (2006). Resource use dynamics and interactions in the tropics: scaling up in space and time. Agricultural Systems, 88, 8-27.

Gnonlonfin, G. J. B., Hell, K., Adjovi, Y., Fandohan, P., Koudande, D. O., Mensah, G. A., \& Brimer, L. (2013). A review on aflatoxin contamination and its implications in the developing world: a sub-Saharan African perspective. Critical Reviews in Food Science and Nutrition, 53(4), 349-365.
Gómez, M. I., Barrett, C. B., Buck, L. E., De Groote, H., Ferris, S., Gao, H. O., \& Yang, R. Y. (2011). Research principles for developing country food value chains. Science, 332(6034), 1154-1155.

Goswami, S. B., Sen, H., \& Jana, P. K. (1995). Tuberization and yield potential of sweetpotato cultivars as influenced by water management practices. Journal of Root Crops, 21, 77-81.

Gregory, P. J., Ingram, J. S. I., \& Brklacich, M. (2005). Climate change and food security. Philosophical Transactions of the Royal Society B, 360, 2139-2148.

Gupta, A. (2012). Pesticide use in South and South-East Asia: environmental public health and legal concerns. American Journal of Environmental Sciences, 8(2), 152-157.

Gupta, R., \& Sayre, K. (2007). Conservation agriculture in South Asia. Journal of Agricultural Science, 145, 207-214.

Haussmann, B. I., Fred-Rattunde, H., Weltzien-Rattunde, E., Traoré, P. S. C., Vom Brocke, K., \& Parzies, H. K. (2012). Breeding strategies for adaptation of pearl millet and sorghum to climate variability and change in West Africa. Journal of Agronomy and Crop Science, 198(5), 327-339.

Heong, K. L., \& Schoenly, K. G. (1998). Impact of insecticides on herbivore-natural enemy communities in tropical rice ecosystems. In P. T. Haskell \& P. McEwen (Eds.), Ecotoxicology: Pesticides and beneficial organisms (pp. 381-403). London: Chapman and Hall.

Hershey, C.H., \& Howeler, R.H. (2000). Cassava in Asia: Designing crop research for competitive markets. In Cassava's potential in Asia in the 21st Century: Present situation and future research and development needs. Proceedings 6th Regional Workshop, held in Ho Chi Minh City, Vietnam, pp. 110-146.

Hobbs, P. R., Sayre, K., \& Gupta, R. (2008). The role of conservation agriculture in sustainable agriculture. Philosophical Transactions of the Royal Society, B: Biological Sciences, 363, 543-555.

Hodges, R. J., Buzby, J. C., \& Bennett, B. (2011). Postharvest losses and waste in developed and less developed countries: opportunities to improve resource use. The Journal of Agricultural Science, 149(S1), $37-45$.

Howeler, R.H. (2000). Cassava agronomy research in Asia: Has it benefited cassava farmers? In Cassava's potential in Asia in the 21st Century: Present situation and future research and development needs. Proceedings 6th Regional Workshop, held in Ho Chi Minh City, Vietnam, pp. 345-382.

Howeler, R. H. (2002). Cassava mineral nutrition and fertilization. In R. J. Hillocks, J. M. Thresh, \& A. Bellotti (Eds.), Cassava: Biology, production and utilization (pp. 115-147). Wallingford: CABI Publishing.

IRRI. (2004). IRRI's Environmental Agenda: an approach toward sustainable development (International Rice Research Institute (IRRI)). Philippines: Manila.

Jarvis, A., Ramirez-Villegas, J., Campo, B. V. H., \& Navarro-Racines, C. (2012). Is cassava the answer to African climate change adaptation? Tropical Plant Biology, 5(1), 9-29.

Jeger, M. J., Gilijamse, E., Bock, C. H., \& Frinking, H. (1998). The epidemiology, variability and control of the downy mildews of pearl millet and sorghum, with particular reference to Africa. Plant Pathology, 47, 544-569.

John, A., \& Fielding, M. (2014). Rice production constraints and 'new' challenges for South Asian smallholders: insights into de facto research priorities. Agriculture \& Food Security, 3(1), 18.

Joshi, P. K., Singh, N. P., Singh, N. N., Gerpacio, R. V., \& Pingali, P. L. (2005). Maize in India: Production systems, constraints, and research priorities. México: CIMMYT.

Kanampiu, F., Ransom, J., Gressel, J., Jewell, D., Friesen, D., Grimanelli, D., \& Hoisington, D. (2002). Appropriateness of biotechnology to African agriculture: Striga and maize as paradigms. Plant Cell, Tissue and Organ Culture, 69(2), 105-110.

Karim, O. R., \& Fasasi, O. S. (2009). Gari yield and chemical composition of cassava roots stored using traditional methods. In African Crop Science Conference Proceedings Vol. 9, pp. 329-332. 
Keating, B. A., Carberry, P. S., Bindraban, P. S., Asseng, S., Meinke, H., \& Dixon, J. (2010). Eco-efficient agriculture: concepts, challenges, and opportunities. Crop Science, 50, S-109-S-119.

Khan, Z., Midega, C., Pittchar, J., Pickett, J., \& Bruce, T. (2011). Pushpull technology: a conservation agriculture approach for integrated management of insect pests, weeds and soil health in Africa. International Journal of Agricultural Sustainability, 9(1), 162-170.

Kijima, Y., Otsuka, K., \& Sserunkuuma, D. (2011). An inquiry into constraints on a green revolution in Sub-Saharan Africa: the case of NERICA rice in Uganda. World Development, 39(1), 77-86.

Knox, J., Hess, T., Daccache, A., \& Wheeler, T. (2012). Climate change impacts on crop productivity in Africa and South Asia. Environmental Research Letters, 7(3), 034032.

Kyamanywa, S., Kashaija, I.N., Getu, E., Amata, R., Senkesha, N., \& Kullaya, A. (2011). Enhancing food security through improved seed systems of appropriate varieties of cassava, potato and sweetpotato resilient to climate change in Eastern Africa. Retrieved from http:// cgspace.cgiar.org/bitstream/handle/10568/10817/Project2_Cassava. pdf? sequence $=6$

Lal, R. (2005). World crop residues production and implications of its use as a biofuel. Environment International, 31(4), 575-584.

Lal, R. (2009). Soil degradation as a reason for inadequate human nutrition. Food Security, 1(1), 45-57.

Larson, D. F., Otsuka, K., Kajisa, K., Estudillo, J., \& Diagne, A. (2010). Can Africa replicate Asia's green revolution in rice? Washington DC: World Bank, Development Research Group, Agriculture and Rural Development Team.

Lebot, V. (2009). Tropical root and tuber crops: Cassava, sweetpotato, yam and aroids. Crop Production Science in Horticulture No, 17. CABI Publishing, Wallingford.

Legg, J. P., Owor, B., Sseruwagi, P., \& Ndunguru, J. (2006). Cassava mosaic virus disease in East and Central Africa: epidemiology and management of a regional pandemic. Advances in Virus Research, $67,355-418$.

Legg, J. P., Jeremiah, S. C., Obiero, H. M., Maruthi, M. N., Ndyetabula, I., Okao-Okuja, G., \& Lava Kumar, P. (2011). Comparing the regional epidemiology of the cassava mosaic and cassava brown streak virus pandemics in Africa. Virus Research, 159(2), 161-170.

Legg, J., Somado, E. A., Barker, I., Beach, L., Ceballos, H., Cuellar, W., Elkhoury, W., Gerling, D., et al. (2014). A global alliance declaring war on cassava viruses in Africa. Food Security, 6(2), 231-248.

Li, X., Waddington, S. R., Dixon, J., Joshi, A. K., \& de Vicente, M. C. (2011). The relative importance of drought and other water related constraints for major food crops in South Asian farming systems. Food Security, 3(1), 19-33.

Lobell, D. B., Schlenker, W., \& Costa-Roberts, J. (2011a). Climate trends and global crop production since 1980. Science, 333(6042), 616-620.

Lobell, D. B., Bänziger, M., Magorokosho, C., \& Vivek, B. (2011b). Nonlinear heat effects on African maize as evidenced by historical yield trials. Nature Climate Change, 1(1), 42-45.

Low, J., Lynam, J., Lemaga, B., Crissman, C., Barker, I., Thiele, G., Namanda, S., et al. (2009). Sweetpotato in Sub-Saharan Africa. In G. Loebenstein \& G. Thottappilly (Eds.), The sweetpotato (pp. 359390). Dordrecht: Springer.

Mapfumo, P., Mtambanengwe, F., Giller, K. E., \& Mpepereki, S. (2005). Tapping indigenous herbaceous legumes for soil fertility management by resource-poor farmers in Zimbabwe. Agriculture, Ecosystems \& Environment, 109(3-4), 221-233.

Mejia, D. (2004). Rice-post harvest system: An efficient approach. Rome: FAO.

Melifonwu, A. A. (1994). Weeds and their control in cassava. African Crop Science Journal, 2(4), 519-530.

Michels, K., Sivakumar, M. V. K., \& Allison, B. E. (1993). Wind erosion in the Southern Sahelian Zone and induced constraints to pearl millet production. Agricultural and Forest Meteorology, 67(1), 65-77.
Mohamed, A. B., Van Duivenbooden, N., \& Abdoussallam, S. (2002). Impact of climate change on agricultural production in the SahelPart 1. Methodological approach and case study for millet in Niger. Climatic Change, 54(3), 327-348.

Mueller, N. D., Gerber, J. S., \& Johnston, M. (2012). Closing yield gaps through nutrient and water management. Nature, 490, 254-257.

Murty, M.V.R., Singh, P., Wani, S.P., Khairwal, I.S., \& Srinivas, K. (2007). Yield gap analysis of sorghum and pearl millet in India using simulation modelling. Global Theme on Agroecosystems Report No 37, ICRISAT, Patancheru.

Mutava, R. N., Prasad, P. V. V., Tuinstra, M. R., Kofoid, K. D., \& Yu, J. (2011). Characterization of sorghum genotypes for traits related to drought tolerance. Field Crops Research, 123(1), 10-18.

Nedunchezhiyan, M. (2011). Evaluation of sweet potato (Ipomoea batatas) based strip intercropping systems for yield, competition indices and nutrient uptake. Indian Journal of Agronomy, 56(2), 98-103.

Norton, G., Heong, K. L., Johnson, D., \& Savary, S. (2010). Rice pest management: issues and opportunities. In S. Pandey, D. Byerlee, D. Dawe, A. Dobermann, M. Samarendu, S. Rozelle, \& B. Hardy (Eds.), Rice in the global economy: Strategic research and policy issues for food security (p. 333). Manila: IRRI.

Oerke, E. C. (2006). Crop losses to pests. Journal of Agricultural Science, 144(1), 31-43.

Oerke, E. C., \& Dehne, H. W. (2004). Safeguarding production-losses in major crops and the role of crop protection. Crop Protection, 23(4), 275-285.

Oluwole, O., \& Cheke, R. A. (2009). Health and environmental impacts of pesticide use practices: a case study of farmers in Ekiti State, Nigeria. International Journal of Agricultural Sustainability, 7(3), 153-163.

Onwueme, I. C. (2002). Cassava in Asia and the Pacific. In R. J. Hillocks, J. M. Thresh, \& A. Bellotti (Eds.), Cassava: Biology, production and utilization (pp. 55-65). Wallingford: CABI Publishing.

Paavola, J. (2008). Livelihoods, vulnerability and adaptation to climate change in Morogoro, Tanzania. Environmental Science \& Policy, 11(7), 642-654.

Paeth, H., Capo-Chichi, A., \& Endlicher, W. (2008). Climate change and food security in tropical West Africa - a dynamic-statistical modelling approach. Erdkunde, 62, 101-115.

Pampolino, M. F., Manguiat, I. J., Ramanathan, S., Gines, H. C., Tan, P. S., Chi, T. T. N., \& Buresh, R. J. (2007). Environmental impact and economic benefits of site-specific nutrient management (SSNM) in irrigated rice systems. Agricultural Systems, 93(1), 1-24.

Pandey, S., Byerlee, D. R., Dawe, D., Dobermann, A., Mohanty, S., Rozelle, S., \& Hardy, B. (2010). Rice in the global economy: strategic research and policy issues for food security. International Rice Research Institute, Los Baños (Philippines).

Patil, B. L., \& Fauquet, C. M. (2009). Cassava mosaic geminiviruses: actual knowledge and perspectives. Molecular Plant Pathology, 10(5), 685-701.

Peng, S., Buresh, R. J., Huang, J., Yang, J., Zou, Y., Zhong, X., \& Wang, G. (2006). Strategies for overcoming low agronomic nitrogen use efficiency in irrigated rice systems in China. Field Crops Research, 96(1), 37-47.

Peters, J. (2000). Control of yam diseases in forest margin farming systems in Ghana. Final technical report. DFID. Available at: http://www.dfid. gov.uk/r4d/PDF/Outputs/CropProtection/R6691_FTR.pdf

Pfwaster, S., Bayer, P., Koehler, A., \& Hellweg, S. (2011). Environmental impacts of water use in global crop production: hotspots and tradeoffs with land use. Environmental Science \& Technology, 45(13), $5761-5768$.

Phalan, P., Onial, M., Balmford, A., \& Green, R. E. (2011). Reconciling food production and biodiversity conservation: land sharing and land sparing compared. Science, 333(6047), 1289-1291.

Phalan, B., Bertzky, M., Butchart, S. H., Donald, P. F., Scharlemann, J. P., Stattersfield, A. J., \& Balmford, A. (2013). Crop expansion and conservation priorities in tropical countries. PLoS One, 8(1), e51759. 
Pingali, P.L. (1995). Impact of pesticides on farmer health and the rice environment: an overview of results from a multidisciplinary study in the Philippines. In Impact of pesticides on farmer health and the rice environment. (pp. 3-21). Springer, Dordrecht.

Pingali, P. L. (2012). Green revolution: impacts, limits, and the path ahead. Proceedings of the National Academy of Sciences, 109(31), 12302-12308.

Pingali, P.L., \& Pandey, S. (2000). Meeting world maize needs: Technological opportunities and priorities for the public sector. CIMMYT, Mexico. Retrieved from http://apps.cimmyt. org/ Research/Economics/map/facts trends/maizeft9900/pdfs/ maizeft9900_Part1a.pdf

Poppy, G. M., Jepson, P. C., Pickett, J. A., \& Birkett, M. A. (2014). Achieving food and environmental security: new approaches to close the gap. Philosophical Transactions of the Royal Society, B: Biological Sciences, 369(1639), 20120272.

Pray, C. E., \& Nagarajan, L. (2009). Pearl millet and sorghum improvement in India. Washington DC: IFPRI Discussion Papers.

Pretty, J. N., Noble, A. D., Bossio, D., Dixon, J., Hine, R. E., Penning de Vries, F. W. T., \& Morison, J. I. L. (2006). Resource-conserving agriculture increases yields in developing countries. Environmental Science \& Technology, 40(4), 1114-1119.

Pretty, J., Toulmin, C., \& Williams, S. (2011). Sustainable intensification in African agriculture. International Journal of Agricultural Sustainability, 9(1), 5-24.

Reay, D. S., Davidson, E. A., Smith, K. A., Smith, P., Melillo, J. M., Dentener, F., \& Crutzen, P. J. (2012). Global agriculture and nitrous oxide emissions. Nature Climate Change, 6, 410-416.

Ringler, C., Zhu, T., Cai, X., Koo, J., \& Wang, D. (2010). Climate change impacts on food security in Sub-Saharan Africa. IFPRI Discussion Paper. Retrieved from http://www.parcc-web.org/parcc-project/ documents/2012/12/climate-change-impacts-on-food-security-insub-saharan-africa.pdf

Rodenburg, J., Zwart, S. J., Kiepe, P., Narteh, L. T., Dogbe, W., \& Wopereis, M. C. (2014). Sustainable rice production in African inland valleys: seizing regional potentials through local approaches. Agricultural Systems, 123, 1-11

Rurinda, J., Mapfumo, P., van Wijk, M. T., Mtambanengwe, F., Rufino, M. C., Chikowo, R., \& Giller, K. E. (2014). Comparative assessment of maize, finger millet and sorghum for household food security in the face of increasing climatic risk. European Journal of Agronomy, 55, 29-41.

Schlenker, W., \& Lobell, D. B. (2010). Robust negative impacts of climate change on African agriculture. Environmental Research Letters, 5(1), 014010.

Shiferaw, B., Prasanna, B. M., Hellin, J., \& Bänziger, M. (2011). Crops that feed the world 6. Past successes and future challenges to the role played by maize in global food security. Food Security, 3(3), 307-327.

Singh, P., Agrawal, P.K., Bhatia, V.S., Murthy, M.V.R., Pala, M., Oweis, T., Benli, B., Rao, K.P.C., \& Wani, S.P. (2009). Yield gap analysis: Modelling of achievable yields at farm level. In Rainfed agriculture: Unlocking the potential. comprehensive assessment of water management in agriculture series 7 (pp. 81-123). Wallingford: CABI Publishing.

Singleton, G. (2003). Impact of rodents on rice production in Asia. IRRI discussion papers. Manila: International Rice Research Institute (IRRI).

Smith, P., Martino, D., Cai, Z., Gwary, D., Janzen, H., Pushpam, K., McCarl, B., et al. (2008). Greenhouse gas mitigation in agriculture. Philosophical Transactions of the Royal Society, B: Biological Sciences, 363(1492), 789-813.

Snapp, S. S., Mafongoya, P. L., \& Waddington, S. (1998). Organic matter technologies for integrated nutrient management in smallholder cropping systems of southern Africa. Agriculture, Ecosystems and Environment, 71, 185-200.

Snapp, S. S., Blackie, M. J., Gilbert, R. A., Bezner-Ker, R., \& Kanyama-Phiri, G. Y. (2010). Biodiversity can support a greener revolution in Africa. Proceedings of the National Academy of Sciences, 107, 20840-20845.

Srivastava, A. K., Gaiser, T., Paeth, H., \& Ewert, F. (2012). The impact of climate change on yam (Dioscorea alata) yield in the savanna zone of West Africa. Agriculture, Ecosystems \& Environment, 153, 57-64.

Stathers, T. E., Rees, D., Kabi, S., Mbilinyi, L., Smit, N., Kiozya, H., \& Jeffries, D. (2003). Sweetpotato infestation by Cylas spp. in East Africa I. Cultivar differences in field infestation and the role of plant factors. International Journal of Pest Management, 49(2), 131-140.

Stevenson, J. R., Serraj, R., \& Cassman, K. G. (2014). Evaluating conservation agriculture for small-scale farmers in Sub-Saharan Africa and South Asia. Agriculture, Ecosystems \& Environment, 187, 1-10.

Strange, R. N., \& Scott, P. R. (2005). Plant disease: a threat to global food security. Annual Review of Phytopathology, 43, 83-116.

Subbarao, G. V., Renard, C., Payne, W. A., \& Bationo, A. (2000). Longterm effects of tillage, phosphorous fertilization and crop rotation on pearl millet-cowpea productivity in the West African Sahel. Experimental Agriculture, 36(2), 243-264.

Sultan, B., Roudier, P., Quirion, P., Alhassane, A., Muller, B., Dingkuhn, M., \& Baron, C. (2013). Assessing climate change impacts on sorghum and millet yields in the Sudanian and Sahelian savannas of West Africa. Environmental Research Letters, 8(1), 14- 40.

Tari, I., Laskay, G., Takacs, Z., \& Poor, P. (2013). Response of Sorghum to abiotic stresses: a review. Journal of Agronomy and Crop Science, 199(4), 264-274.

Tefera, T. (2012). Post-harvest losses in African maize in the face of increasing food shortage. Food Security, 4(2), 267-277.

Thierfelder, C., Cheesman, S., \& Rusinamhodzi, L. (2012). A comparative analysis of conservation agriculture systems: benefits and challenges of rotations and intercropping in Zimbabwe. Field Crops Research, 137, 327-250.

Thornton, P. (2012). Recalibrating food production in the developing world: Global warming will change more than just the climate. CGIAR. Retrieved from http://cgspace.cgiar.org/bitstream/handle/10568/ 24696/CCAFS PB06-Recalibrating\%20Food\%20Production.pdf

Tilman, D., Balzer, C., Hill, J., \& Befort, B. L. (2011). Global food demand and the sustainable intensification of agriculture. Proceedings of the National Academy of Sciences, 108(50), 20260-20264.

Timsina, J., Jat, M. L., \& Majumdar, K. (2010). Rice-maize systems of South Asia: current status, future prospects and research priorities for nutrient management. Plant and Soil, 335(1-2), 65-82.

Timsina, J., Buresh, R. J., Dobermann, A., \& Dixon, J. (2011). Rice-maize systems in Asia: Current situation and potential. Manila: IRRI.

Tittonell, P., Vanlauwe, B., Corbeels, M., \& Giller, K. E. (2008). Yield gaps, nutrient use efficiencies and response to fertilizers by maize across heterogeneous smallholder farms of western Kenya. Plant and Soil, 313, 19-37.

Tuong, T. P., Bouman, B. A. M., \& Mortimer, M. (2005). More rice, less water - integrated approaches for increasing water productivity in irrigated rice-based systems in Asia. Plant Production Science, 8, 231-240.

Twomlow, S., Rohrbach, D., Dimes, J., Rusike, J., Mupangwa, W., Ncube, B., Hove, L., Moyo, M., Mashingaidze, N., \& Mahposa, P. (2010). Micro-dosing as a pathway to Africa's Green Revolution: evidence from broad-scale on-farm trials. Nutrient Cycling in Agroecosystems, 88(1), 3-15.

Uphoff, N., Kassam, A., \& Stoop, W. (2008). A critical assessment of a desk study comparing crop production systems: the example of the 'System of Rice Intensification' versus ‘Best Management Practice'. Field Crops Research, 108, 109-114.

Valbuena, D., Erenstein, O., Homann-Kee Tui, S., Abdoulaye, T., Claessens, L., Duncan, A. J., \& van Wijk, M. T. (2012). 
Conservation agriculture in mixed crop-livestock systems: scoping crop residue trade-offs in Sub-Saharan Africa and South Asia. Field Crops Research, 132, 175-184.

Valverde, R. A., Clark, C. A., \& Valkonen, J. P. (2007). Viruses and virus disease complexes of sweetpotato. Plant Viruses, 1(1), 116-126.

van Ittersum, M. K., Cassman, K. G., Grassini, P., Wolf, J., Tittonell, P., \& Hochman, Z. (2013). Yield gap analysis with local to global relevance - a review. Field Crops Research, 143, 4-17.

Vanlauwe, B., Bationo, A., Chianu, J., Giller, K. E., Merckx, R., Mokwunye, U., Ohiokpehai, O., Pypers, P., Tabo, R., Shepherd, K. D., Smaling, E. M. A., Woomer, P. L., \& Sanginga, N. (2010). Integrated soil fertility management: operational definition and consequences for implementation and dissemination. Outlook on Agriculture, 39(1), 17-24.

Wada, Y., van Beek, L. P., van Kempen, C. M., Reckman, J. W., Vasak, S., \& Bierkens, M. F. (2010). Global depletion of groundwater resources. Geophysical Research Letters, 37(20), L20402.

Waddington, S.R., Edmeades, G.O., Chapman, S.C. \& Barreto, H.J. (1995). Where to with agricultural research for drought-prone maize environments? In: Maize Research for Stress Environments (Jewell, D.C., Waddington, S.R., Ransom, J.K. and Pixley, K.V., eds.), Proceedings of the Fourth Eastern and Southern Africa Regional Maize Conference, Harare, Zimbabwe. (pp. 129-152). CIMMYT, Mexico, D.F., Mexico.

Waddington, S. R., Mekuria, M., Siziba, S., \& Karigwindi, J. (2007). Long-term yield sustainability and financial returns from grain legume-maize intercrops on a sandy soil in subhumid north central Zimbabwe. Experimental Agriculture, 43(4), 489-503.

Waddington, S. R., Li, X., Dixon, J., Hyman, G., \& de Vicente, M. C. (2010). Getting the focus right: production constraints for six major food crops in Asian and African farming systems. Food Security, 2(1), 27-48.

Waha, K., Müller, C., Bondeau, A., Dietrich, J. P., Kurukulasuriya, P., Heinke, J., \& Lotze-Campen, H. (2013). Adaptation to climate change through the choice of cropping system and sowing date in subSaharan Africa. Global Environmental Change, 23(1), 130-143.

Williams, R. J., \& Rao, K. N. (1981). A review of sorghum grain molds. International Journal of Pest Management, 27(2), 200-211.

Williamson, S., Ball, A., \& Pretty, J. (2008). Trends in pesticide use and drivers for safer pest management in four African countries. Crop Protection, 27(10), 1327-1334.

Witcombe, J.R., \& Beckerman, S.R. (1987). Proceedings of the International Pearl Millet Workshop, International Crops Research Institute for the Semi-Arid Tropics, Andhra Pradesh, India, 7-11 Apr 1986.

Witt, C., Buresh, R. J., Peng, S., Balsubramanian, V., \& Doberman, A. (2007). Nutrient management. In T. Fairhurst, C. Witt, R. Buresh, \& A. Doberman (Eds.), Rice: A practical guide to nutrient management. Manila: International Rice Research Institute (IRRI).

World Bank. (2011). Missing food: the case of postharvest grain losses in Sub-Saharan Africa. Retrieved from http://siteresources.worldbank. org/INTARD/Resources/MissingFoods10_web.pdf

Wydra, K., \& Verdier, V. (2002). Occurrence of cassava diseases in relation to environmental, agronomic and plant characteristics. Agriculture, Ecosystems and Environment, 93(1-3), 211-226.

Yan, X., Akiyama, H., Yagi, K., \& Akimoto, H. (2009). Global estimations of the inventory and mitigation potential of methane emissions from rice cultivation conducted using the 2006 Intergovernmental Panel on Climate Change Guidelines. Global Biogeochemical Cycles, 23, GB2002.

Yusuf, R. O., Noor, Z. Z., Abba, A. H., Hassan, M. A. A., \& Din, M. F. M. (2012). Methane emission by sectors: a comprehensive review of emission sources and mitigation methods. Renewable and Sustainable Energy Reviews, 16(7), 5059-5070.

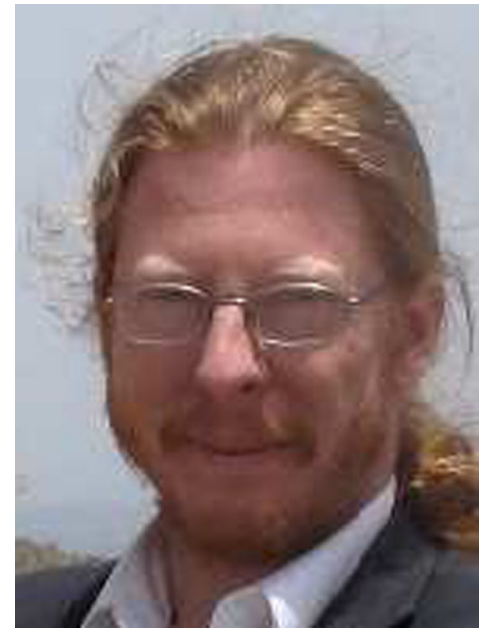

Travis W. Reynolds is Assistant Professor of Environmental Studies at Colby College, with a $\mathrm{PhD}$ in Public Policy and Management from the University of Washington. Travis has 10 years of experience with agro-forestry and sustainable agriculture extension and research in West and East Africa, including service as an agro-forestry trainer through the U.S Peace Corps in Senegal. His main research interests include ecosystem services flows from human-modified landscapes, environmental impacts of food systems, payments for ecosystem services (PES) and related institutional incentives for conservation behavior, and food and environmental policy. His recent work has included a U.S. National Science Foundation-funded project examining the institutional structures and ecological impacts of sacred natural sites in Ethiopia, along with studies of non-timber forest product (NTFP) value chain development opportunities along the Ethiopia-Sudanese border, and several research projects with the Evans School Policy Analysis and Research team at the University of Washington and the Bill and Melinda Gates Foundation.

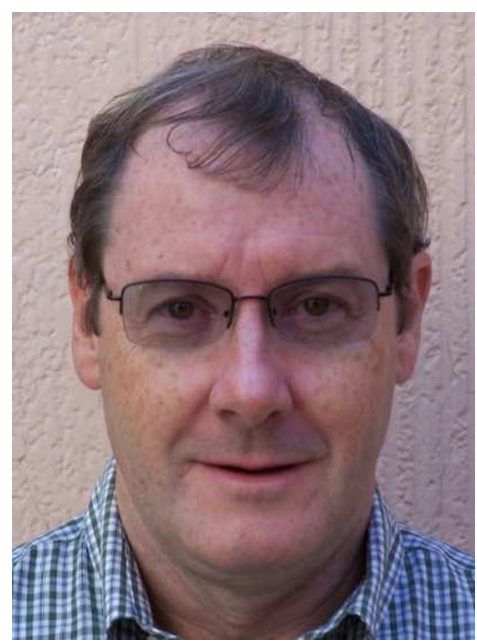

Stephen Waddington is an agronomist, with a $\mathrm{PhD}$ on the yield physiology of barley, obtained from the University of Reading, UK in 1983. He has around 30 years of experience with agricultural research and development in southern and eastern Africa, south Asia and Mexico, most of it while working with CIMMYT. His main research interests have involved smallholder farming systems and participatory research, maize and wheat crop production agronomy and seed systems, soil fertility management for maize-legume cropping systems, water management, crop-livestock interactions, environmental impacts of cropping systems, and cereal yield physiology. $\mathrm{He}$ has also been closely involved with capacity building and networking initiatives in several of these areas, including 10 years as coordinator of the Soil Fertility Network for Southern Africa, funded by the Rockefeller Foundation. Stephen is currently an independent agricultural consultant and is based in Mexico. His recent work has included maize advisor to Katalyst-Swisscontact in Bangladesh, support to the Michigan State University-Africa Rising project in Malawi and this research on cropenvironment interactions with the University of Washington-Bill and Melinda Gates Foundation. 


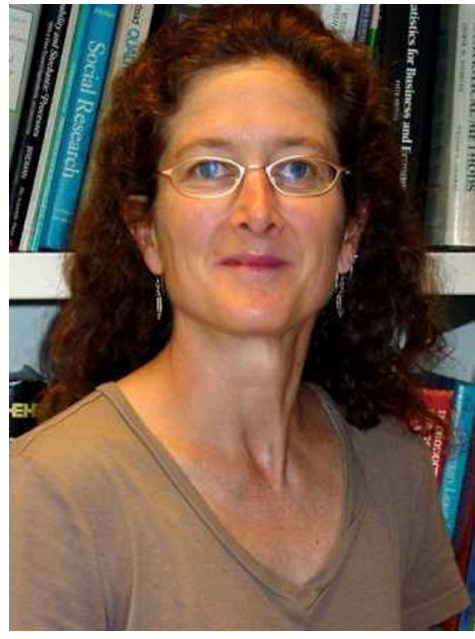

C. Leigh Anderson is the Marc Lindenberg Professor of Humanitarian Action, International Development and Global Citizenship, and Associate Dean of Innovation at the University of Washington's Daniel J. Evans School of Public Affairs. Her primary research interest is in how individuals and households living in poverty make financial, environmental, health, and other livelihood decisions, especially when outcomes are highly risky or spread over time. Her current research focuses on rural poverty and agriculture, and market and policy institutions, including the UW-USAID Women's Agricultural Value project for Cassava in Tanzania. Leigh is also the founder and PI of the Evans School Policy Analysis and Research Group (EPAR) that provides ongoing research support to Agricultural Development, Development Policy and Finance, and Financial Services for the Poor at the Bill and Melinda Gates Foundation. She previously taught for 8 years at Carleton University in Ottawa, Canada and has also taught or been a visiting researcher at the University of California at Berkeley, Lahore University of Management Sciences in Pakistan, Renmin University of China in Beijing, and the United Nations Food and Agriculture Organization in Rome.

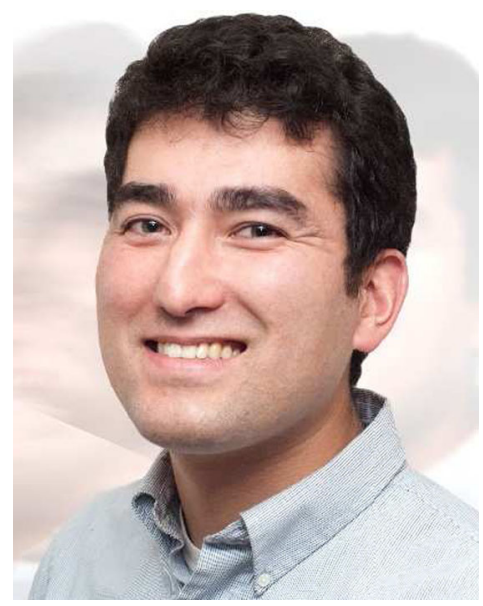

Alexander Chew holds a Master of Public Administration (MPA) from the Evans School of Public Affairs at the University of Washington, and is currently a consultant at ORS Impact, a strategy and evaluation firm located in Seattle, Washington. Previously, he worked for the Evans School Policy Analysis and Research Group (EPAR), which provides policy analysis and research support to the Agricultural Team at the Bill \& Melinda Gates Foundation. His professional interests include agricultural and development policy and program evaluation.

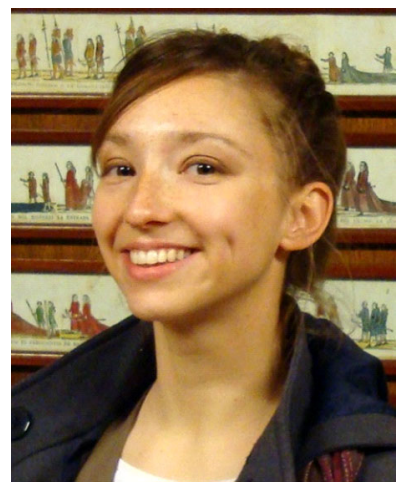

Zoë True is a graduate research assistant at the University of Washington's Evans School of Public Affairs, concentrating her graduate work on global health and nonprofit management. She served in the United States Peace Corps in Morocco where she directed projects on women's health and agriculture. Zoë earned her Master of Arts in political science at the California

State University, Long Beach and has 5 years of work experience in campaigns and the nonprofit sector.

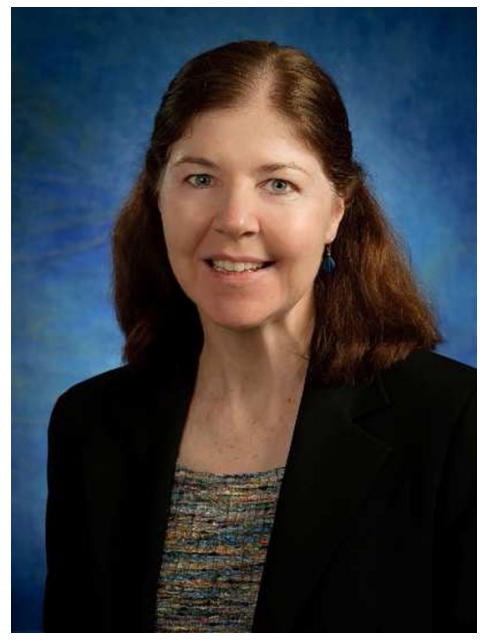

Alison Cullen is a risk and decision analyst, with a ScD from the Harvard School of Public Health. She has 30 years of experience with positions in academia, consulting and at the US Environmental Protection Agency. Her research interests are focused on decision making under uncertainty applied to environmental health, and the risk/ opportunity balance introduced by emerging technology in the areas of energy, food systems and health. Her most recent work has been funded by the Nation-

al Science Foundation and the Alfred P. Sloan Foundation. Alison has served on the faculty of the Daniel J. Evans School of Public Affairs at the University of Washington in Seattle for the past 20 years. 